\title{
Detection of Magnesite and Associated Gangue Minerals Using Hyperspectral Remote Sensing-A Laboratory Approach
}

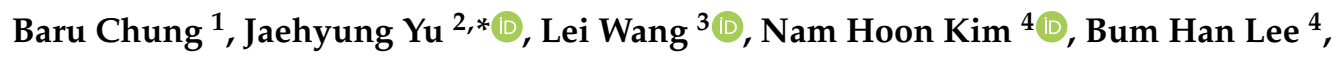 \\ Sangmo Koh ${ }^{4}$ and Sangin Lee ${ }^{5}$ \\ 1 Department of Astronomy, Space Science and Geology, Chungnam National University, Daejeon 34134, \\ Korea; cbaru@o.cnu.ac.kr \\ 2 Department of Geological Sciences, Chungnam National University, Daejeon 31134, Korea \\ 3 Department of Geography \& Anthropology, Louisiana State University, Baton Rouge, LA 70803, USA; \\ leiwang@lsu.edu \\ 4 Convergence Research Center for Development of Mineral Resources (DMR), Korea Institute of Geoscience \\ and Mineral Resources, Daejeon 34132, Korea; nhkim@kigam.re.kr (N.H.K.); leebh@kigam.re.kr (B.H.L.); \\ kohsm@kigam.re.kr (S.K.) \\ 5 Department of Information and Statistics, Chungnam National University, Daejeon 31134, Korea; \\ sanginlee44@gmail.com \\ * Correspondence: jaeyu@cnu.ac.kr; Tel.: +82-42-821-6426
}

Received: 26 March 2020; Accepted: 20 April 2020; Published: 22 April 2020 updates

\begin{abstract}
This study introduced a detection method for magnesite and associated gangue minerals, including dolomite, calcite, and talc, based on mineralogical, chemical, and hyperspectral analyses using hand samples from thirteen different source locations and Specim hyperspectral short wave infrared (SWIR) hyperspectral images. Band ratio methods and logistic regression models were developed based on the spectral bands selected by the random forest algorithm. The mineralogical analysis revealed the heterogeneity of mineral composition for naturally occurring samples, showing various carbonate and silicate minerals as accessory minerals. The $\mathrm{Mg}$ and $\mathrm{Ca}$ composition of magnesite and dolomite varied significantly, inferring the mixture of minerals. The spectral characteristics of magnesite and associated gangue minerals showed major absorption features of the target minerals mixed with the absorption features of accessory carbonate minerals and talc affected by mineral composition. The spectral characteristics of magnesite and dolomite showed a systematic shift of the $\mathrm{Mg}-\mathrm{OH}$ absorption features toward a shorter wavelength with an increased $\mathrm{Mg}$ content. The spectral bands identified by the random forest algorithm for detecting magnesite and gangue minerals were mainly associated with spectral features manifested by $\mathrm{Mg}-\mathrm{OH}, \mathrm{CO}_{3}$, and $\mathrm{OH}$. A two-step band ratio classification method achieved an overall accuracy of $92 \%$ and $55.2 \%$. The classification models developed by logistic regression models showed a significantly higher accuracy of 98 99.9\% for training samples and $82-99.8 \%$ for validation samples. Because the samples were collected from heterogeneous sites all over the world, we believe that the results and the approach to band selection and logistic regression developed in this study can be generalized to other case studies of magnesite exploration.
\end{abstract}

Keywords: magnesite; gangue mineral; hyperspectral; random forest; logistic regression; natural occurrence; exploration 


\section{Introduction}

Magnesite $\left(\mathrm{MgCO}_{3}\right)$ is one of the major source minerals for $\mathrm{Mg}$ ore [1]. It occurs as crystalline or cryptocrystalline forms by serpentine alteration, fissure filling, or metasomatic ore deposits of limestone or dolostone. The major occurrence is associated with limestone and dolostone, where calcite $\left(\mathrm{CaCO}_{3}\right)$, dolomite $\left(\mathrm{CaMg}\left(\mathrm{CO}_{3}\right)_{2}\right)$, and talc $\left(\mathrm{Mg}_{3} \mathrm{Si}_{4} \mathrm{O}_{10}(\mathrm{OH})_{2}\right)$ are commonly found as gangue minerals. Magnesium is a major resource for various industrial uses including alloy materials, refractories, fertilizers, drug medicines, and automobile engines [2,3]. There are more than 60 minerals containing wide ranges of magnesium concentration. Differently from dolomite and magnesite, host rocks such as limestone and marble accompany $\mathrm{Mg}$ as an accessory element, while magnesite has a high $\mathrm{Mg} / \mathrm{Ca}$ ratio by concentration [4].

Magnesite mineralization is mainly associated with the evaporation of Mg-rich fluid and secondary recrystallization during the diagenesis process of carbonate rocks that originated from marine, evaporite, lagoon, and lacustrine environments [5-10]. Moreover, the replacement of carbonate rocks by Mg-rich hydrothermal fluid often produces abundant dolomite and magnesite bodies [8,11-13]. Dolomitization can occur at relatively lower temperature in a marine environment and is controlled by variations in the $\mathrm{Mg} / \mathrm{Ca}$ content in carbonate rocks. Differently from dolomite, magnesite mineralization only occurs at a relatively higher temperature $\left(>60^{\circ} \mathrm{C}\right)$ with elevating $\mathrm{CO}_{2}$ pressure. On the other hand, talc mineralization mainly occurs in hydrothermal activities on dolomite and magnesite [14,15], where the silicate composition originates from the hydrothermal solution and the carbonate composition originates from dolomite and/or magnesite. Due to the geological characteristics, magnesite mineralization is mainly associated with carbonate rocks with talc as an accessory mineral, and thus, the commonly found gangue minerals are calcite, dolomite, and talc.

Carbonate minerals including calcite, dolomite, and magnesite show similar mineral properties [16-18], and thus, it is relatively hard to discern these minerals in the field, and such work was mostly conducted using staining methods (e.g., Alizarine Red) $[19,20]$ or laboratory techniques (e.g., X-ray diffraction) [21]. However, the traditional methods are labor and time intensive, requiring many steps of analytical procedures including field sampling, sample preparation, and analysis. Compared to the traditional laboratory tests, high efficiency and non-destructive spectroscopic analysis using hand-held spectrometers or airborne hyperspectral remote sensing were proposed to expedite the mineral classification. Specifically, superior to multispectral remote sensing [22-27], hyperspectral images have been collected for mineralogy studies from space-borne [28-30], air-borne [31,32], or ground-based platforms [33-35]. For example, [30] explored hydrothermal alteration zones for the limestone area based on EO-1 Hyperion data and defined dolomite and chlorite distributions. [29] distinguished Trona (Na-carbonate mineral) from evaporites and chert with $84 \%$ accuracy using the EO-1 Hyperion data. [28] tested hyperspectral airborne system (AVIRIS) and a spaceborne system (Hyperion) to detect calcite, clay minerals, and silicate minerals in Nevada, US. [31] mapped clay minerals, ore minerals, and dolomite with AVIRIS at $50 \%$ accuracy due to the similarity of spectral features. [32] classified calcite, pyrite, chalcopyrite, and silicate minerals for hydrothermal alteration studies by employing HyMap. The low accuracy of the mineral mapping from satellites and airborne systems calls for more ground surveys and spectroscopic analyses to provide additional in situ knowledge of the spectral properties of minerals. [34] defined the zonation of limestone and dolostone using a HySpex-320m Specim hyperspectral short wave infrared (SWIR) hyperspectral scanner. [33] detected limestone, dolostone, chert-cemented dolostone, fossiliferous limestone, chert, and carbonate nodules in a sedimentary layer with $80 \%$ accuracy using a SWIR hyperspectral scanner. [35] determined the $\mathrm{Ca} / \mathrm{Mg}$ content in dolomite and calcite using a SisuCHEMA hyperspectral scanner.

The spectral characteristics of carbonate minerals such as magnesite, dolomite, and calcite are mainly controlled by the combination of carbonate and cations [36,37]. Those minerals have common absorption features manifested by $\mathrm{CO}_{3}$ at 1800 and $2160 \mathrm{~nm}$. The absorption feature at $2300 \mathrm{~nm}$ is controlled by the proportion between $\mathrm{Mg}$ and Ca contents [33]. The absorption feature causes a minor shift in spectral position, which is affected by its $\mathrm{Mg}$ and Ca content, where the absorption of magnesite 
is at $2300 \mathrm{~nm}$, that of dolomite is at $2320 \mathrm{~nm}$, and that of calcite is at $2340 \mathrm{~nm}$ [34]. The mixture of those minerals would make complications in the spectral signatures. The spectral characteristics of talc had distinctive absorptions at $1400 \mathrm{~nm}$, caused by hydrolysis components and doublet absorptions at $2300 \mathrm{~nm}$ of the $\mathrm{MgOH}$ component [38]. Due to the common absorptions and variations in the absorption positions of magnesite and gangue minerals, the natural occurrence with the mixture of those minerals would increase the complexity of its spectral classification.

Sufficient spectroscopic evidence for magnesite exploration is lacking given that many have put their efforts into mapping carbonate minerals with limestone and dolostone, because of not only the high cost in spectroscopic data collection, but also the heterogeneity of the geologic settings of different case studies. Indeed, geological applications are often site-specific, and thus, mapping techniques at one site are not applicable to other sites. The objective of this research is to provide a generalizable spectroscopic regression model for mapping magnesite and associated gangue minerals. This has been accomplished by collecting spectroscopic samples from a variety of sites and conducting a comprehensive analysis of the spectral characteristics of the samples with different mineral compositions. We expect that this study may form the basis for airborne or satellite-based approaches.

\section{Materials and Methods}

\subsection{Sample Selection}

Magnesite ore mostly occurs in carbonate rocks such as limestone and dolostone, mixed with gangue minerals including dolomite, calcite, and talc. This study used the magnesite samples collected from sites in China, North Korea, and South Korea. In fact, North Korea and China account for 38\% of overall magnesite reserves all over the world [39]. Notably, China produces $70 \%$ of the magnesite.

We collected a total of 113 magnesite and associated mineral hand samples from China, North Korea, and South Korea sites, including 28 magnesite samples from 4 different locations, 38 dolomite samples from 6 different locations, 30 limestone samples from 6 different locations, and 17 talc samples from 3 different locations. The sample sizes ranged from 3 to $23 \mathrm{~cm}$ in diameter. In addition, we included 12 other types of rock sample to verify if the models in this study worked with other types of rock (Table 1). We used 20 magnesite, 17 dolomite, 21 limestone, 12 talc, and 9 other type samples for training the regression models and 8 magnesite, 21 dolomite, 5 talc, 9 calcite, and 3 other type samples for validation (Table 1), based on a random selection.

Table 1. The source locations and types of sample used in this study.

\begin{tabular}{|c|c|c|c|c|c|c|c|c|}
\hline ID & Location & Type & ID & Location & Type & ID & Location & Type \\
\hline 1 & Muhak, N.K & $\mathrm{M}(\mathrm{T})$ & 43 & Geomdeog, N.K & $\mathrm{D}(\mathrm{T})$ & 85 & Sinwol, S.K & $\mathrm{C}(\mathrm{T})$ \\
\hline 2 & Daehung, N.K & $\mathrm{M}(\mathrm{T})$ & 44 & Geomdeog, N.K & $\mathrm{D}(\mathrm{T})$ & 86 & Sinwol, S.K & $\mathrm{C}(\mathrm{T})$ \\
\hline 3 & Dashiqiao, C & $\mathrm{M}(\mathrm{T})$ & 45 & Dashiqiao, C & $\mathrm{D}(\mathrm{T})$ & 87 & Sinwol, S.K & $\mathrm{C}(\mathrm{T})$ \\
\hline 4 & Muhak, N.K & $\mathrm{M}(\mathrm{T})$ & 46 & Sungshin, S.K & $\mathrm{D}(\mathrm{V})$ & 88 & Jecheon, S.K & $\mathrm{C}(\mathrm{V})$ \\
\hline 5 & Dashiqiao, C & $\mathrm{M}(\mathrm{T})$ & 47 & Sungshin, S.K & $\mathrm{D}(\mathrm{V})$ & 89 & Hansol, S.K & $\mathrm{C}(\mathrm{V})$ \\
\hline 6 & Ryongyang, N.K & $\mathrm{M}(\mathrm{T})$ & 48 & Sungshin, S.K & $\mathrm{D}(\mathrm{V})$ & 90 & Hansol, S.K & $\mathrm{C}(\mathrm{V})$ \\
\hline 7 & Ryongyang, N.K & $\mathrm{M}(\mathrm{T})$ & 49 & Sungshin, S.K & $\mathrm{D}(\mathrm{V})$ & 91 & Hansol, S.K & $\mathrm{C}(\mathrm{V})$ \\
\hline 8 & Ryongyang, N.K & $\mathrm{M}(\mathrm{T})$ & 50 & Mungok, S.K & $\mathrm{D}(\mathrm{V})$ & 92 & Sinwol, S.K & $\mathrm{C}(\mathrm{V})$ \\
\hline 9 & Ryongyang, N.K & $\mathrm{M}(\mathrm{T})$ & 51 & Mungok, S.K & $\mathrm{D}(\mathrm{V})$ & 93 & Sinwol, S.K & $\mathrm{C}(\mathrm{V})$ \\
\hline 10 & Ryongyang, N.K & $\mathrm{M}(\mathrm{T})$ & 52 & Mungok, S.K & $\mathrm{D}(\mathrm{V})$ & 94 & Sinwol, S.K & $\mathrm{C}(\mathrm{V})$ \\
\hline 11 & Ryongyang, N.K & $\mathrm{M}(\mathrm{T})$ & 53 & Yeongwol, S.K & $\mathrm{D}(\mathrm{V})$ & 95 & Jecheon, S.K & $\mathrm{C}(\mathrm{V})$ \\
\hline 12 & Ryongyang, N.K & $\mathrm{M}(\mathrm{T})$ & 54 & Yeongwol, S.K & $\mathrm{D}(\mathrm{V})$ & 96 & Geumsan, S,K & $\mathrm{C}(\mathrm{V})$ \\
\hline 13 & Ryongyang, N.K & $\mathrm{M}(\mathrm{T})$ & 55 & Yeongwol, S.K & $\mathrm{D}(\mathrm{V})$ & 97 & Dashiqiao, C & $\mathrm{T}(\mathrm{T})$ \\
\hline 14 & Muhak, N.K & $\mathrm{M}(\mathrm{T})$ & 56 & Yeongwol, S.K & $\mathrm{D}(\mathrm{V})$ & 98 & Myeongjin, S.K & $\mathrm{T}(\mathrm{T})$ \\
\hline 15 & Ryongyang, N.K & $\mathrm{M}(\mathrm{T})$ & 57 & Yeongwol, S.K & $\mathrm{D}(\mathrm{V})$ & 99 & Myeongjin, S.K & $\mathrm{T}(\mathrm{T})$ \\
\hline 16 & Daehung, N.K & $\mathrm{M}(\mathrm{T})$ & 58 & Yeongwol, S.K & $\mathrm{D}(\mathrm{V})$ & 100 & Myeongjin, S.K & $\mathrm{T}(\mathrm{T})$ \\
\hline 17 & Daehung, N.K & $\mathrm{M}(\mathrm{T})$ & 59 & Yeongwol, S.K & $\mathrm{D}(\mathrm{V})$ & 101 & Myeongjin, S.K & $\mathrm{T}(\mathrm{T})$ \\
\hline 18 & Daehung, N.K & $\mathrm{M}(\mathrm{T})$ & 60 & Yeongwol, S.K & $\mathrm{D}(\mathrm{V})$ & 102 & Myeongjin, S.K & $\mathrm{T}(\mathrm{T})$ \\
\hline 19 & Daehung, N.K & $\mathrm{M}(\mathrm{T})$ & 61 & Jecheon, S.K & $\mathrm{D}(\mathrm{V})$ & 103 & Myeongjin, S.K & $\mathrm{T}(\mathrm{T})$ \\
\hline 20 & Daehung, N.K & $\mathrm{M}(\mathrm{T})$ & 62 & Jecheon, S.K & $\mathrm{D}(\mathrm{V})$ & 104 & Myeongjin, S.K & $\mathrm{T}(\mathrm{T})$ \\
\hline
\end{tabular}


Table 1. Cont.

\begin{tabular}{|c|c|c|c|c|c|c|c|c|}
\hline ID & Location & Type & ID & Location & Type & ID & Location & Type \\
\hline 21 & Ryongyang, N.K & $\mathrm{M}(\mathrm{V})$ & 63 & Jecheon, S.K & $\mathrm{D}(\mathrm{V})$ & 105 & Myeongjin, S.K & $\mathrm{T}(\mathrm{T})$ \\
\hline 22 & Ryongyang, N.K & $\mathrm{M}(\mathrm{V})$ & 64 & Jecheon, S.K & $\mathrm{D}(\mathrm{V})$ & 106 & Myeongjin, S.K & $\mathrm{T}(\mathrm{T})$ \\
\hline 23 & Daehung, N.K & $\mathrm{M}(\mathrm{V})$ & 65 & Geomdeog, N.K & $\mathrm{D}(\mathrm{V})$ & 107 & Myeongjin, S.K & $\mathrm{T}(\mathrm{T})$ \\
\hline 24 & Daehung, N.K & $\mathrm{M}(\mathrm{V})$ & 66 & Geomdeog, N.K & $\mathrm{D}(\mathrm{V})$ & 108 & Myeongjin, S.K & $\mathrm{T}(\mathrm{T})$ \\
\hline 25 & Daehung, N.K & $\mathrm{M}(\mathrm{V})$ & 67 & Myeongjin, S.K & $\mathrm{C}(\mathrm{T})$ & 109 & Myeongjin, S.K & $\mathrm{T}(\mathrm{V})$ \\
\hline 26 & Daehung, N.K & $\mathrm{M}(\mathrm{V})$ & 68 & Myeongjin, S.K & $\mathrm{C}(\mathrm{T})$ & 110 & Myeongjin, S.K & $\mathrm{T}(\mathrm{V})$ \\
\hline 27 & Daehung, N.K & $\mathrm{M}(\mathrm{V})$ & 69 & Myeongjin, S.K & $\mathrm{C}(\mathrm{T})$ & 111 & Myeongjin, S.K & $\mathrm{T}(\mathrm{V})$ \\
\hline 28 & Daehung, N.K & $\mathrm{M}(\mathrm{V})$ & 70 & Myeongjin, S.K & $\mathrm{C}(\mathrm{T})$ & 112 & Myeongjin, S.K & $\mathrm{T}(\mathrm{V})$ \\
\hline 29 & Sungshin, S.K & $\mathrm{D}(\mathrm{T})$ & 71 & Myeongjin, S.K & $\mathrm{C}(\mathrm{T})$ & 113 & Geumsan, S.K & $\mathrm{T}(\mathrm{V})$ \\
\hline 30 & Sungshin, S.K & $\mathrm{D}(\mathrm{T})$ & 72 & Myeongjin, S.K & $\mathrm{C}(\mathrm{T})$ & 114 & Sinwol, S.K & $\mathrm{O}(\mathrm{T})$, Sandstone \\
\hline 31 & Dashiqiao, C & $\mathrm{D}(\mathrm{T})$ & 73 & Hansol, S.K & $\mathrm{C}(\mathrm{T})$ & 115 & Sinwol, S.K & $\mathrm{O}(\mathrm{T})$, Shale \\
\hline 32 & Mungok, S.K & $\mathrm{D}(\mathrm{T})$ & 74 & Hansol, S.K & $\mathrm{C}(\mathrm{T})$ & 116 & Sinwol, S.K & $\mathrm{O}(\mathrm{T})$, Tuff \\
\hline 33 & Mungok, S.K & $\mathrm{D}(\mathrm{T})$ & 75 & Hansol, S.K & $\mathrm{C}(\mathrm{T})$ & 117 & Sinwol, S.K & $\mathrm{O}(\mathrm{T})$, Igneous rock \\
\hline 34 & Mungok, S.K & $\mathrm{D}(\mathrm{T})$ & 76 & Hansol, S.K & $\mathrm{C}(\mathrm{T})$ & 118 & Sinwol, S.K & $\mathrm{O}(\mathrm{T})$, Sandstone \\
\hline 35 & Mungok, S.K & $\mathrm{D}(\mathrm{T})$ & 77 & Hansol, S.K & $\mathrm{C}(\mathrm{T})$ & 119 & Sinwol, S.K & $\mathrm{O}(\mathrm{T})$, Conglomerate \\
\hline 36 & Yeongwol, S.K & $\mathrm{D}(\mathrm{T})$ & 78 & Myeongjin, S.K & $\mathrm{C}(\mathrm{T})$ & 120 & Sinwol, S.K & $\mathrm{O}(\mathrm{T})$, Mudstone \\
\hline 37 & Yeongwol, S.K & $\mathrm{D}(\mathrm{T})$ & 79 & Myeongjin, S.K & $\mathrm{C}(\mathrm{T})$ & 121 & Sinwol, S.K & $\mathrm{O}(\mathrm{T})$, Shale \\
\hline 38 & Jecheon, S.K & $\mathrm{D}(\mathrm{T})$ & 80 & Myeongjin, S.K & $\mathrm{C}(\mathrm{T})$ & 122 & Sinwol, S.K & $\mathrm{O}(\mathrm{T})$, Conglomerate \\
\hline 39 & Jecheon, S.K & $\mathrm{D}(\mathrm{T})$ & 81 & Myeongjin, S.K & $\mathrm{C}(\mathrm{T})$ & 123 & Sinwol, S.K & $\mathrm{O}(\mathrm{V})$, Sandstone \\
\hline 40 & Geomdeog, N.K & $\mathrm{D}(\mathrm{T})$ & 82 & Sinwol, S.K & $\mathrm{C}(\mathrm{T})$ & 124 & Sinwol, S.K & $\mathrm{O}(\mathrm{V})$, Tuff \\
\hline 41 & Geomdeog, N.K & $\mathrm{D}(\mathrm{T})$ & 83 & Sinwol, S.K & $\mathrm{C}(\mathrm{T})$ & 125 & Sinwol, S.K & $\mathrm{O}(\mathrm{V})$, Shale \\
\hline 42 & Geomdeog, N.K & $\mathrm{D}(\mathrm{T})$ & 84 & Sinwol, S.K & $\mathrm{C}(\mathrm{T})$ & & & \\
\hline
\end{tabular}

Location: $\mathrm{S} . \mathrm{K}=$ South Korea, N.K = North Korea, $\mathrm{C}=$ China. Type: $\mathrm{M}=$ magnesite ore, $\mathrm{D}=$ dolomite, $\mathrm{C}=$ calcite, $\mathrm{T}=$ talc, $\mathrm{O}=$ other type. $(\mathrm{T})=$ training samples, $(\mathrm{V})=$ validation samples.

\subsection{Mineral Composition Analysis}

In the real world, pure carbonate minerals are rarely found, and any natural sample might include a mixture of different minerals. Therefore, the hard classification of mineral types by referencing to a spectral library is almost impossible for making sense. To measure the mineral composition of the samples, we carried out X-ray Diffraction (XRD hereafter) analysis using a D8 Advance diffractometer (Bruker-AXS) with a Cu target and LynxEye position sensitive detector. The parameters for diffraction pattern acquisition were a step size of $0.01^{\circ}, 2 \theta$ range of $5^{\circ}-100^{\circ}, 1 \mathrm{sec}$ counting time for each step, and $30 \mathrm{rpm}$ in PE bottles. The fundamental parameters were calibrated with standard materials (LaB6, NIST SRM 660b) with the same conditions. The representative portion of the hand samples were selected based on the visual inspection and cut. The cutting surface of each slab was sanded to remove contamination. The processed samples were air dried for one day to get rid of their moisture and crushed with rock hammers and jaw crushers. The quadrisect samples were powdered with the agate mortar for the XRD analysis and with a tungsten carbide disc mill for X-ray fluorescence (XRF hereafter) spectrometry analysis.

\subsection{Chemical Analysis}

As mentioned, both magnesite and dolomite contain $\mathrm{MgO}$ and $\mathrm{CaO}$, whereas magnesite has more $\mathrm{Mg}$ content, and thus, the two minerals often show similar patterns in their spectral signatures. Moreover, the $\mathrm{MgO}$ content of one specific mineral varies significantly due to the impurities of naturally formed minerals. To analyze the spectral characteristics of magnesite and dolomite associated with $\mathrm{MgO}$ and $\mathrm{CaO}$ content, we analyzed $\mathrm{MgO}$ and $\mathrm{CaO}$ content based on Lab XRF analysis. Of each preprocessed sample, $1 \mathrm{~g}$ was mixed with $5.5 \mathrm{~g}$ of Li-tetraborate $\left(\mathrm{Li}_{2} \mathrm{~B}_{4} \mathrm{O}_{7}\right)$ in a platinum crucible. The mixed samples were entirely melted in a gas furnace at $1100{ }^{\circ} \mathrm{C}$ for 10 minutes. The glass beads were prepared by quenching the totally molten mixed samples in a polished platinum mold. These glass beads were used for the XRF analyses. The analytical errors for $\mathrm{MgO}$ and $\mathrm{CaO}$ were within $1 \%$. We analyzed the $\mathrm{Mg}$ and Ca content of all 28 magnesite samples and 38 dolomite samples using the powered samples selected in the previous step. 


\subsection{Hyperspectral Image Acquisition and Preprocessing}

The hyperspectral images of the samples were acquired by a Specim hyperspectral short wave infrared (SWIR) camera (Spectral Imaging Ltd, Finland) in a laboratory conditions. The SWIR imaging spectrometer has a spectral range of 1000-2500 nm, with a $15 \mathrm{~nm}$ bandwidth and $5.6 \mathrm{~nm}$ spectral sampling, producing hyperspectral images of 288 bands for 384 spatial pixels. For the Lambertian reflectance data acquisition, the samples were leveled to the camera nadir view, with a halogen lamp as the light source. The white reference panel (Spectralon material with 99\% reflectance) was stationed next to the samples in the field of view for radiometric calibration.

The acquired hyperspectral images were preprocessed following the workflow of [33,40]. Moreover, the image pixels corresponding to the sample images were selected for further processing, excluding the background pixels. The radiance recorded by the sensor was calibrated with the empirical line method, using the reflectance panel, and converted to reflectance spectra [41]. In addition, we applied the maximum noise fraction (MNF) transformation to remove random noise in the hyperspectral data [42]. The noise bands were determined by the eigenvalues less or equal to 2 . Previous studies (e.g., [43]) suggested cut-off eigenvalues of 2 for maximum noise removal without disturbance of the original data, where approximately 120 dimensions were retained in this study. The noise bands were then replaced with zero values and the data were transformed back to the spectral domain by inverse MNF transformation.

The denoised hyperspectral reflectance of the samples was extracted and transformed with a hull quotient correction. The hull quotient correction techniques enhance absorption features in reflectance spectra and are efficient for the detection of the position and depth of the absorption characteristics [44]. The hull quotient corrected spectra were used to analyze the spectral characteristics associated with mineral composition for all carbonate minerals, as well as the spectral variations associated with $\mathrm{Mg}$ and Ca content for dolomite and magnesite.

\section{Classification Model Development}

\subsection{Band Importance Filtering by Random Forest}

This study used band ratio method and logistic regression models to derive simplified open classification models that are applicable in other cases of magnesite exploration based on laboratory hyperspectral approaches. To reduce the number of variables for model construction, a random forest (RF) algorithm was employed to select the best representative bands for magnesite and gangue associated mineral classification. The RF algorithm is a machine learning and ensemble-based model [45-47]. Although RF models can do classification and regression as well, one of its useful aspects in addition to the regression function is its ability to rank the variable importance by the Gini index [48]. The Gini index is also called the impurity index. It is used by the decision tree algorithm to select the best variable for splitting the samples. The lowest Gini index represents the most important variable in the classification model. The RF is developed based on a bootstrap sample [45]. The model grows trees from random sampling on the dataset and the variables. The RF model uses $2 / 3$ (known as "in-bag") samples for the training set, and the remaining 1/3 (known as "out-of-bag") for accuracy assessment by cross-validation [45]. The randomly selected subsets of variables are created by user-defined number of features (known as "Mtry"), and the random forest grows to the user-defined number of trees (known as "Ntree"). The final classification is decided based on majority votes from all the trees. Two parameters need to be set in order to produce the forest trees: Ntree and Mtry. In general, the RF classifier can have the maximum number of trees (Ntree) due to its strength of no over-fit. However, we assigned 500 Ntree for this study, as previous studies revealed that the final decision is commonly made before Ntree reaches 500 [49]. The Mtry parameter is set to the square root of the number of input variables [50]. For band selection, we extracted 1000 pixels from each sample image containing information for 269 spectral bands and selected 30 bands derived from the RF model as a by-product for the derivation of band ratios and logistic regression models for the 
classification of magnesite and associated gangue minerals. We used the SPSS random forest package for band selection.

\subsection{Band Ratio}

The band ratio is a commonly used multiband image processing method to enhance differences in spectral characteristics and remove environmental biases such as illumination variation and shadows [51-53], which has often been used for hyperspectral data classification [54,55]. For selecting the best band radio combination from the 30 bands selected by the RF algorithm, we created a simple band assemblage based on the 30 bands:

$$
\mathrm{Y}=\sum_{k}^{30} \frac{X_{k}}{X_{n}}(\mathrm{n}=1,2,3, \ldots, 30)
$$

Each band ratio for mineral classes was tested by ANOVA tests, and the tested band combination was further statistically analyzed by the Tamhane $T_{2}$ test [56] to compare classification performance among the mineral classes. The band combination with the best classification performance was further analyzed to define index ranges, indicating each class by box plots. The band combination classified carbonate minerals and other types including talc and other types of rock.

\subsection{Multi-Variate Logistic Regression}

While the band ratio method can select two bands at a time, a multi-variate logistic regression model includes all candidate bands in one model to detect mineral existence. The logistic regression method is a statistical method developed for the analysis and classification of categorical variables [57-59]. Therefore, the method is an appropriate approach for detection of a specific mineral [60]. The logistic regression assumes that the occurrence of binary response variable $(Y)$ is controlled by variable $(X)$ and, thus, creates two class plots indicating the event $(Y=1)$ and no event $(Y=0)$. The logistic function derives a probability model based on input variables and transforms the probability value to 0 or 1 based on the cut-off value of $0.5[58,61]$. We derived a logistic regression model for each mineral class based on the reflectance value of 30 selected bands from the RF model, following Equations (2) and (3) [62].

$$
\operatorname{Logit}(\mathrm{P})_{\text {mineral }}=\ln \left(\frac{P}{1-P}\right)=\mathrm{C}+\beta_{1} \mathrm{X}_{1}+\beta_{2} \mathrm{X}_{2}+\ldots+\beta_{n} \mathrm{X}_{n}
$$

where $\operatorname{Logit}(P)_{\text {mineral }}$ indicates the logistic probability of specific mineral occurrence, $\mathrm{C}$ is the intercept value, $\beta$ are the contributions of the covariates to the probability of dependent variable occurrence, and $X$ is the reflectance value of the selected band. Then, the probability of the target event is calculated as

$$
P_{\text {mineral }}=\frac{e^{(\mathrm{C}+\beta 1 \mathrm{X} 1+\beta 2 \times 2 \ldots+\beta \mathrm{n} X \mathrm{n})}}{1+e^{(\mathrm{C}+\beta 1 \mathrm{X} 1+\beta 2 \times 2 \ldots+\beta \mathrm{n} \times \mathrm{n})}}
$$

The final $p$ value of a mineral occurrence is assigned as either 1 or 0 based on the 0.5 cut-off value [63]. The logistic regression models developed for each mineral were evaluated by -2 log-likelihood(-2LL) tests and Hosmer and Lemeshow tests. The -2LL evaluates the goodness of fit for the model based on the maximum likelihood regarding the observation and prediction dataset, where a lower value indicates a better fit [64]. The Hosmer and Lemeshow tests evaluate a model based on a log-likelihood ratio between the observation and prediction values, where a model with the highest ratio is considered to have the highest statistical significance [65]. In addition, two coefficients of determination, pseudo- $\mathrm{R}^{2}$ values of "Cox and Snell" and "Nagelkerke", were used to evaluate the logistic regression models [66,67]. The pseudo- $R^{2}$ values are calculated as

$$
R^{2}=1-\left\{\frac{L\left(M_{C}\right)}{L\left(M_{\beta}\right)}\right\}^{\frac{2}{N}}, \text { Cox and Snell }
$$




$$
R^{2}=\frac{1-\left\{\frac{L\left(M_{C}\right)}{L\left(M_{\beta}\right)}\right\}^{\frac{2}{N}}}{1-L\left(M_{\beta}\right)^{\frac{2}{N}}}, \text { Nagelkerke }
$$

where $L\left(M_{C}\right)$ is the log-likelihood for a model without explanatory variables, and $L\left(M_{\beta}\right)$ is the $\log$-likelihood for a model with the explanatory variables. Both pseudo- $\mathrm{R}^{2}$ values range from 0 to 1 , where values closer to 1 indicate better model effectiveness [68]. Moreover, the Wald statistic $\left((\mathrm{b} / \text { standard error })^{2}\right)$ was used to evaluate the statistical significance of each explanatory variable [58].

\section{Results and Discussion}

\subsection{Mineral Composition of Mineral Samples Associated with Magnesite}

The XRD analysis revealed the mineral composition of the magnesite, dolomite, calcite, and talc samples in this study (Table 2). The mineral composition of the magnesite samples from four different origins showed a various combination of accessory minerals. The results confirmed that the natural occurrence of magnesite ore was not pure and was in the form of mineral mixtures. The accessory minerals include dolomite, calcite, chabazite, clinochlore, quartz, and siderite, where dolomite occurred in all magnesite samples. Differently from magnesite samples, dolomite and calcite samples showed significant variations in mineral composition (Table 2), as they are also considered as major rock forming minerals of carbonate rocks. Talc samples contained magnesite, dolomite, and calcite as accessory minerals (Table 2).

Given the fact that carbonate rocks mainly consist of calcite and dolomite and that magnesite mineralization is mainly associated with carbonate rocks with talc as an accessory mineral, pure minerals with a $100 \%$ concentration of a specific mineral are rare in field samples. Depending on the involvement of hydrothermal activity, evaporation, replacement, and recrystallization, the compositional combination of calcite, dolomite, magnesite, and talc varies significantly. The results indicate heterogeneous mineral compositions, even for the same types of sample. Because the mineral composition in one type of mineral showed large variations in the mixture of magnesite, dolomite, and calcite, it is highly possible that the spectral information of the spectral library may not be able to detect natural occurrence. Therefore, hyperspectral approaches for magnesite exploration must consider variations in mineral composition for expanded applicability in real-world cases.

Table 2. The mineral compositions of the samples used in this study.

\begin{tabular}{|c|c|c|c|c|}
\hline ID & Origin & Type & Major Mineral & Accessory Mineral \\
\hline 1 & Muhak, N.K & Magnesite & Magnesite & Siderite \\
\hline 2 & Daehung, N.K & Magnesite & Magnesite, Dolomite, Chlinochlore & Calcite \\
\hline 3 & Dashiqiao, $\mathrm{C}$ & Magnesite & Magnesite & Dolomite, Talc \\
\hline 4 & Muhak, N.K & Magnesite & Magnesite & Quartz \\
\hline 5 & Dashiqiao, $\mathrm{C}$ & Magnesite & Magnesite & Dolomite \\
\hline 6 & Ryongyang, N.K & Magnesite & Magnesite & Chabazite, Calcite \\
\hline 7 & Ryongyang, N.K & Magnesite & Magnesite & Dolomite \\
\hline 8 & Ryongyang, N.K & Magnesite & Magnesite & Dolomite \\
\hline 9 & Ryongyang, N.K & Magnesite & Magnesite & Dolomite \\
\hline 10 & Ryongyang, N.K & Magnesite & Magnesite & Dolomite \\
\hline 11 & Ryongyang, N.K & Magnesite & Magnesite & Dolomite \\
\hline 12 & Ryongyang, N.K & Magnesite & Magnesite & \\
\hline 13 & Ryongyang, N.K & Magnesite & Magnesite & Dolomite \\
\hline 14 & Muhak, N.K & Magnesite & Magnesite & Quartz \\
\hline 15 & Ryongyang, N.K & Magnesite & Magnesite & \\
\hline 16 & Daehung, N.K & Magnesite & Magnesite & Calcite \\
\hline 17 & Daehung, N.K & Magnesite & Magnesite & \\
\hline 18 & Daehung, N.K & Magnesite & Magnesite & \\
\hline 19 & Daehung, N.K & Magnesite & Magnesite & \\
\hline 20 & Daehung, N.K & Magnesite & Magnesite & Dolomite \\
\hline 21 & Ryongyang, N.K & Magnesite & Magnesite & Dolomite \\
\hline
\end{tabular}


Table 2. Cont.

\begin{tabular}{|c|c|c|c|c|}
\hline ID & Origin & Type & Major Mineral & Accessory Mineral \\
\hline 22 & Ryongyang, N.K & Magnesite & Magnesite & Dolomite \\
\hline 23 & Daehung, N.K & Magnesite & Magnesite & Dolomite \\
\hline 24 & Daehung, N.K & Magnesite & Magnesite & Dolomite \\
\hline 25 & Daehung, N.K & Magnesite & Magnesite & Dolomite \\
\hline 26 & Daehung, N.K & Magnesite & Magnesite & \\
\hline 27 & Daehung, N.K & Magnesite & Magnesite & \\
\hline 28 & Daehung, N.K & Magnesite & Magnesite & Dolomite \\
\hline 29 & Sungshin, S.K & Dolomite & Dolomite & Calcite, Magnesite, Quartz \\
\hline 30 & Sungshin, S.K & Dolomite & Dolomite, Magnesite & Calcite, Chlinochlore Quartz \\
\hline 31 & Dashiqiao, C & Dolomite & Dolomite & Calcite \\
\hline 32 & Mungok, S.K & Dolomite & Dolomite & Quartz \\
\hline 33 & Mungok, S.K & Dolomite & Dolomite & Quartz \\
\hline 34 & Mungok, S.K & Dolomite & Dolomite & Quartz \\
\hline 35 & Mungok, S.K & Dolomite & Dolomite & \\
\hline 36 & Yeongwol, S.K & Dolomite & Dolomite & \\
\hline 37 & Yeongwol, S.K & Dolomite & Dolomite & Magnesite \\
\hline 38 & Jecheon, S.K & Dolomite & Dolomite & Actinolite, Phlogopite \\
\hline 39 & Jecheon, S.K & Dolomite & Dolomite & Actinolite, Augite \\
\hline 40 & Geomdeog, N.K & Dolomite & Dolomite & \\
\hline 41 & Geomdeog, N.K & Dolomite & Dolomite & \\
\hline 42 & Geomdeog, N.K & Dolomite & Dolomite & \\
\hline 43 & Geomdeog, N.K & Dolomite & Dolomite & \\
\hline 44 & Geomdeog, N.K & Dolomite & Dolomite & \\
\hline 45 & Dashiqiao, C & Dolomite & Dolomite & Calcite \\
\hline 46 & Sungshin, S.K & Dolomite & Dolomite & \\
\hline 47 & Sungshin, S.K & Dolomite & Dolomite & \\
\hline 48 & Sungshin, S.K & Dolomite & Dolomite & \\
\hline 49 & Sungshin, S.K & Dolomite & Dolomite & \\
\hline 50 & Mungok, S.K & Dolomite & Dolomite & Quartz \\
\hline 51 & Mungok, S.K & Dolomite & Dolomite, Calcite & Quartz \\
\hline 52 & Mungok, S.K & Dolomite & Dolomite & Quartz \\
\hline 53 & Yeongwol, S.K & Dolomite & Dolomite, Quartz & \\
\hline 54 & Yeongwol, S.K & Dolomite & Dolomite & Magnesite \\
\hline 55 & Yeongwol, S.K & Dolomite & Dolomite & Quartz \\
\hline 56 & Yeongwol, S.K & Dolomite & Dolomite & \\
\hline 57 & Yeongwol, S.K & Dolomite & Dolomite & Magnesite \\
\hline 58 & Yeongwol, S.K & Dolomite & Dolomite & Quartz \\
\hline 59 & Yeongwol, S.K & Dolomite & Dolomite & Quartz \\
\hline 60 & Yeongwol, S.K & Dolomite & Dolomite & \\
\hline 61 & Jecheon, S.K & Dolomite & Dolomite, Calcite & Magnesite \\
\hline 62 & Jecheon, S.K & Dolomite & Dolomite & \\
\hline 63 & Jecheon, S.K & Dolomite & Dolomite, Calcite & \\
\hline 64 & Jecheon, S.K & Dolomite & Dolomite, Calcite & Titanite \\
\hline 65 & Geomdeog, N.K & Dolomite & Dolomite & Calcite \\
\hline 66 & Geomdeog, N.K & Dolomite & Dolomite & Calcite \\
\hline 67 & Myeongjin, S.K & Calcite & Calcite & Magnesite, Dolomite \\
\hline 68 & Myeongjin, S.K & Calcite & Calcite, Dolomite & \\
\hline 69 & Myeongjin, S.K & Calcite & Calcite & \\
\hline 70 & Myeongjin, S.K & Calcite & Calcite, Graphite & \\
\hline 71 & Myeongjin, S.K & Calcite & Calcite & \\
\hline 72 & Myeongjin, S.K & Calcite & Calcite & \\
\hline 73 & Hansol, S.K & Calcite & Calcite & Magnesite \\
\hline 74 & Hansol, S.K & Calcite & Calcite & \\
\hline 75 & Hansol, S.K & Calcite & Calcite & Magnesite \\
\hline 76 & Hansol, S.K & Calcite & Calcite & Magnesite \\
\hline 77 & Hansol, S.K & Calcite & Calcite & \\
\hline 78 & Myeongjin, S.K & Calcite & Calcite & \\
\hline 79 & Myeongjin, S.K & Calcite & Calcite & Magnesite \\
\hline 80 & Myeongjin, S.K & Calcite & Calcite, Dolomite & \\
\hline 81 & Myeongjin, S.K & Calcite & Calcite, Dolomite & \\
\hline 82 & Sinwol, S.K & Calcite & Calcite, Quartz & \\
\hline 83 & Sinwol, S.K & Calcite & Calcite & Quartz \\
\hline 84 & Sinwol, S.K & Calcite & Calcite & Quartz \\
\hline 85 & Sinwol, S.K & Calcite & Calcite & Quartz \\
\hline 86 & Sinwol, S.K & Calcite & Calcite, Quartz & \\
\hline 87 & Sinwol, S.K & Calcite & Calcite & \\
\hline 88 & Jecheon, S.K & Calcite & Calcite, Magnesite, Dolomite & \\
\hline 89 & Hansol, S.K & Calcite & Calcite & Magnesite \\
\hline 90 & Hansol, S.K & Calcite & Calcite, Magnesite & \\
\hline 91 & Hansol, S.K & Calcite & Calcite & Magnesite \\
\hline 92 & Sinwol, S.K & Calcite & Calcite & \\
\hline 93 & Sinwol, S.K & Calcite & Calcite & \\
\hline 94 & Sinwol, S.K & Calcite & Calcite & \\
\hline
\end{tabular}


Table 2. Cont.

\begin{tabular}{|c|c|c|c|c|}
\hline ID & Origin & Type & Major Mineral & Accessory Mineral \\
\hline 95 & Jecheon, S.K & Calcite & Calcite & \\
\hline 96 & Geumsan, S,K & Calcite & Calcite & Quartz \\
\hline 97 & Dashiqiao, C & Talc & Talc, Calcite & Magnesite \\
\hline 98 & Myeongjin, S.K & Talc & Talc & \\
\hline 99 & Myeongjin, S.K & Talc & Talc & \\
\hline 100 & Myeongjin, S.K & Talc & Talc, Dolomite & \\
\hline 101 & Myeongjin, S.K & Talc & Talc & \\
\hline 102 & Myeongjin, S.K & Talc & Talc, Dolomite & \\
\hline 103 & Myeongjin, S.K & Talc & Talc, Dolomite & \\
\hline 104 & Myeongjin, S.K & Talc & Talc, Dolomite & \\
\hline 105 & Myeongjin, S.K & Talc & Talc, Dolomite & \\
\hline 106 & Myeongjin, S.K & Talc & Talc & \\
\hline 107 & Myeongjin, S.K & Talc & Talc, Dolomite & \\
\hline 108 & Myeongjin, S.K & Talc & Talc, Dolomite & \\
\hline 109 & Myeongjin, S.K & Talc & Talc & \\
\hline 110 & Myeongjin, S.K & Talc & Talc & \\
\hline 111 & Myeongjin, S.K & Talc & Talc, Dolomite & \\
\hline 112 & Myeongjin, S.K & Talc & Talc & \\
\hline 113 & Geumsan, S.K & Talc & Talc & \\
\hline
\end{tabular}

\section{2. $\mathrm{MgO}$ and $\mathrm{CaO}$ Content of Magnesite and Dolomite}

The major compositional difference between magnesite $\left(\mathrm{MgCO}_{3}\right)$ and dolomite $\left(\mathrm{CaMg}\left(\mathrm{CO}_{3}\right)_{2}\right)$ is mainly determined by $\mathrm{Mg}$ and Ca contents, where magnesite rarely contains $\mathrm{Ca}$ and dolomite contains low $\mathrm{Mg}$. The chemical composition of magnesite samples from four different locations showed relatively constant $\mathrm{MgO}$ and $\mathrm{CaO}$ contents (Table 3). The $\mathrm{MgO}$ content of magnesite samples ranged from $45.5 \%$ to $47.6 \%$, with very low $\mathrm{CaO}$ content $(<0.79 \%)$. Compared to magnesite, dolomite samples from six different locations showed larger compositional variation, showing $\mathrm{MgO}$ content ranging from $13.7 \%$ to $21.7 \%$ and $\mathrm{CaO}$ content ranging from $21.0 \%$ to $30.8 \%$ (Table 3 ). The stoichiometry studies on magnesite revealed that decreases in $\mathrm{Ca}, \mathrm{Mg}, \mathrm{HCO}_{3}$, and the $\mathrm{Ca} / \mathrm{Mg}$ ratio in carbonate fluid (calcite and aragonite) caused magnesite and dolomite mineralization. Dolomite mineralization takes the $\mathrm{Ca}$ from the carbonate fluid, resulting in a combination of $\mathrm{Mg}$ and Ca contents. Differently from dolomite mineralization, magnesite mineralization occurs at relatively higher temperatures associated with recrystallization, reducing Ca phase replacement in the mineral structure [69]. This result confirms the mineral identification of magnesite and dolomite samples, and variations in Ca composition between the minerals may cause the mineral spectral signature to change. Given the fact that mineral composition and chemical composition are heterogeneous and vary by origin, spectral variation associated with these components accompanies.

Table 3. The average $\mathrm{MgO}$ and $\mathrm{CaO}$ contents of representative magnesite and dolomite samples based on X-ray fluorescence (XRF) analysis.

\begin{tabular}{ccccc}
\hline Location & Type & Number of Samples & MgO & CaO \\
\hline Muhak, N.K & Magnesite & 3 & 45.5 & 0.65 \\
Dashiqiao, C & Magnesite & 2 & 47.5 & 0.79 \\
Ryongyang, N.K & Magnesite & 11 & 47.6 & 0.73 \\
Daehung, N.K & Magnesite & 12 & 47.4 & 0.65 \\
Sungshin, S.K & Dolomite & 6 & 13.7 & 21.0 \\
Mungok, S.K & Dolomite & 7 & 13.8 & 21.1 \\
Yeongwol, S.K & Dolomite & 10 & 20.8 & 29.5 \\
Jecheon, S.K & Dolomite & 6 & 20.5 & 28.8 \\
Geomdeog, N.K & Dolomite & 7 & 21.7 & 30.8 \\
Dashiqiao, C & Dolomite & 2 & 21.6 & 30.7 \\
\hline
\end{tabular}




\subsection{Spectral Characteristics Associated with Mineral Composition}

\subsubsection{Spectral Characteristics of Magnesite Samples}

Spectral analysis on the hull-quoted reflectance spectra of magnesite samples identified strong absorption features at 1850, 1930, 2130, 2300, and $2450 \mathrm{~nm}$, and weak absorption features at 1720 and $2360 \mathrm{~nm}$ (Figure 1). Comparing the spectra of magnesite with the JPL (Jet Propulsion Laboratory) reference spectrum, the overlaps in absorption features could only be found at 1389, 1920, 2300, and $2450 \mathrm{~nm}$. The absorption features of the samples at 1720, 1850, and $2130 \mathrm{~nm}$ are manifested by dolomite, and that at $2360 \mathrm{~nm}$ is affected by calcite and talc.

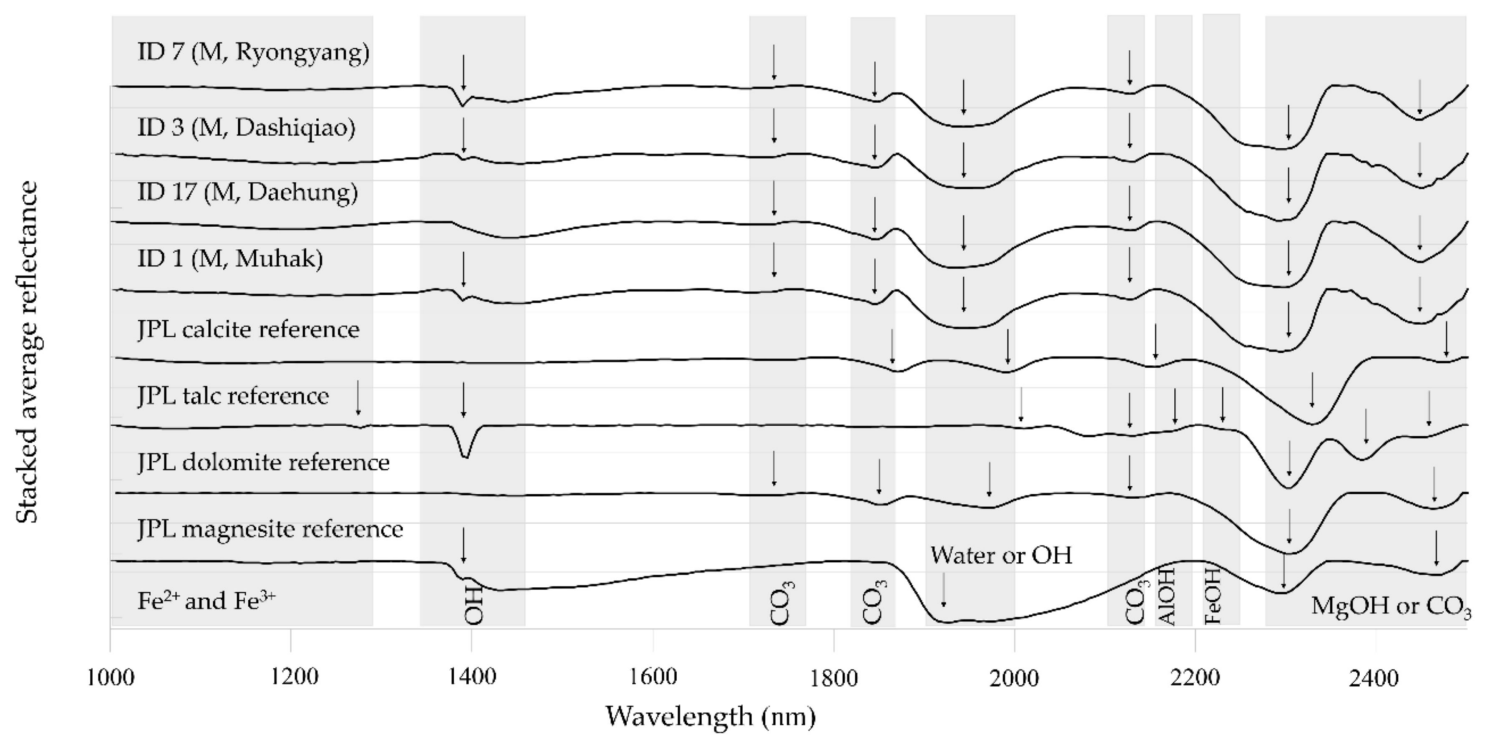

Figure 1. The average hull quotient corrected reflectance spectra of magnesite sample pixels compared with those from library spectra.

\subsubsection{Spectral Characteristics of Dolomite Samples}

The spectral characteristics of dolomite can be subdivided to three groups based on mineral composition and absorption features (Figure 2). Comparing the absorption features of the three groups, only two absorptions at $2320 \mathrm{~nm}$ of $\mathrm{Mg}-\mathrm{OH}$ and $2460 \mathrm{~nm}$ of $\mathrm{CaCO}_{3}$ overlaps for all groups. Group 1 includes samples from Sungshin, Geomdeog and Dashiqiao, where calcite accompanies dolomite as a common accessory mineral. The absorption features of group 1 spectra were found at 1860, 2320, and $2460 \mathrm{~nm}$. Group 2 includes samples from Yeongwol and Mungok, where quartz occurs as a common accessory mineral. The absorption features of the group were located at $1900 \mathrm{~nm}$, with additional absorption at $1440 \mathrm{~nm}$, where calcite occurs as an accessory mineral. Group 3 of samples from Jecheon has unique spectral characteristics, showing a smaller number of absorption features and weaker absorptions. The group contains relatively complicated mineral compositions (Table 2). The absorption features were detected at 1389 and $1920 \mathrm{~nm}$ of the magnesite signal; at 1720, 2140, and $2320 \mathrm{~nm}$ of the dolomite signal; and at $2470 \mathrm{~nm}$ of calcite signal. As the results showed, the spectral characteristics of dolomite varied by mineral composition. Comparing the spectral characteristics between magnesite samples and dolomite samples, many absorption features overlap, and the condition is case dependent. It confirms our concern that even when using the hyperspectral images, the magnesite and dolomite samples are hardly separable by simple classification methods and need comprehensive spectral analyses and band selection. 


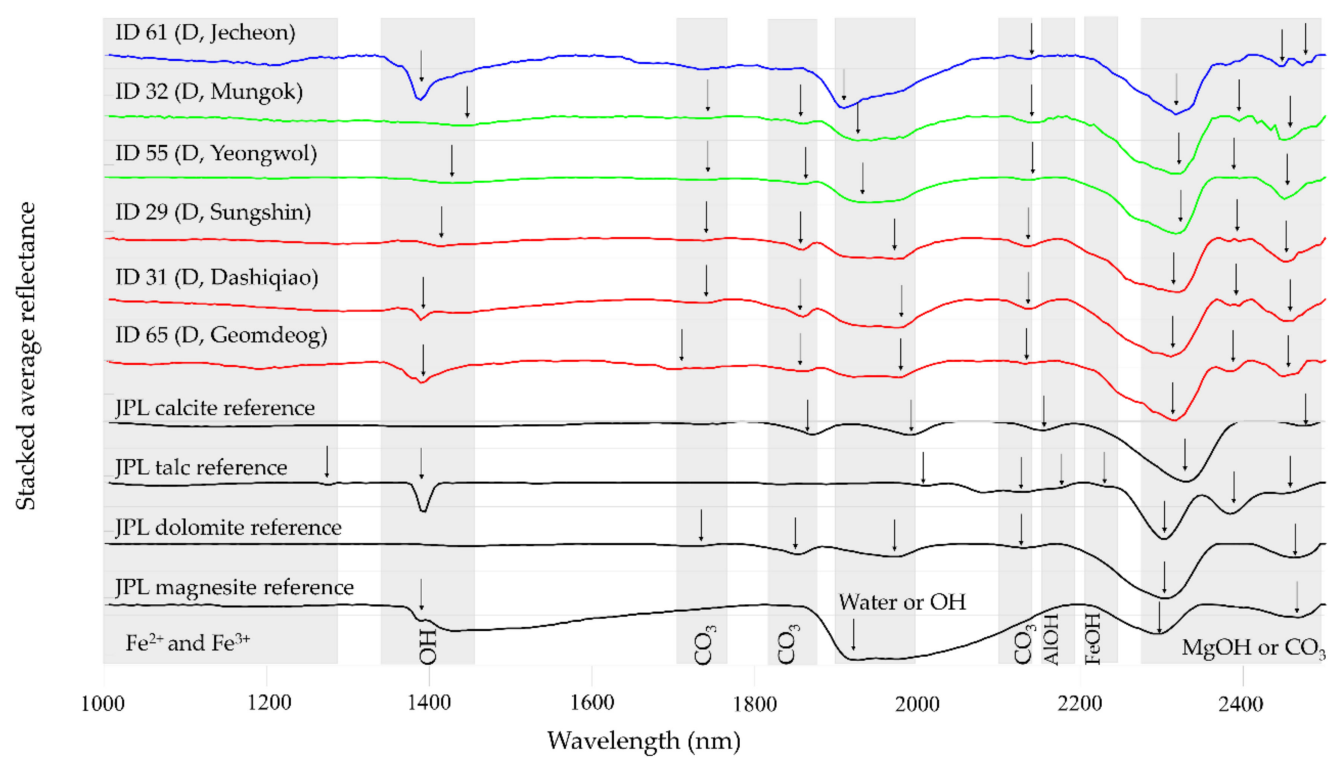

Figure 2. The average hull quotient corrected reflectance spectra of 3 groups of dolomite sample pixels $($ red $=$ group 1 ; green $=$ group 2 ; blue $=$ group 3$)$ compared with library reference spectra .

\subsubsection{Spectral Characteristics of Calcite Samples}

The spectral characteristics of calcite samples can be subdivided to two types. Group 1 includes samples from Myeongjin, Hansol, and Jecheon. The absorption features of group 1 occur at 1394, $1440,1730,1920,2294,2340,2470$, and $2450 \mathrm{~nm}$, where absorptions at 1440, 2340, and $2470 \mathrm{~nm}$ are associated with calcite, and those at 1394, 1920, 2294, and $2450 \mathrm{~nm}$ are manifested by magnesite. Additional absorptions of dolomite were found at $1730 \mathrm{~nm}$ (Figure 3). These spectral characteristics indicate that they were affected by accessory minerals (Table 2). On the other hand, the spectral curves of group 2 from Sinwol and Geumsan have relatively simple analytical features, where accessory minerals were rarely found. The absorption features of calcite mainly control the spectral characteristics, where absorptions were found at 1411, 1876, 1990, 2160, 2340, and $2470 \mathrm{~nm}$ (Figure 3). In the same manner as the other minerals, the calcite samples show large variations in absorption features caused by heterogeneous mineral composition.

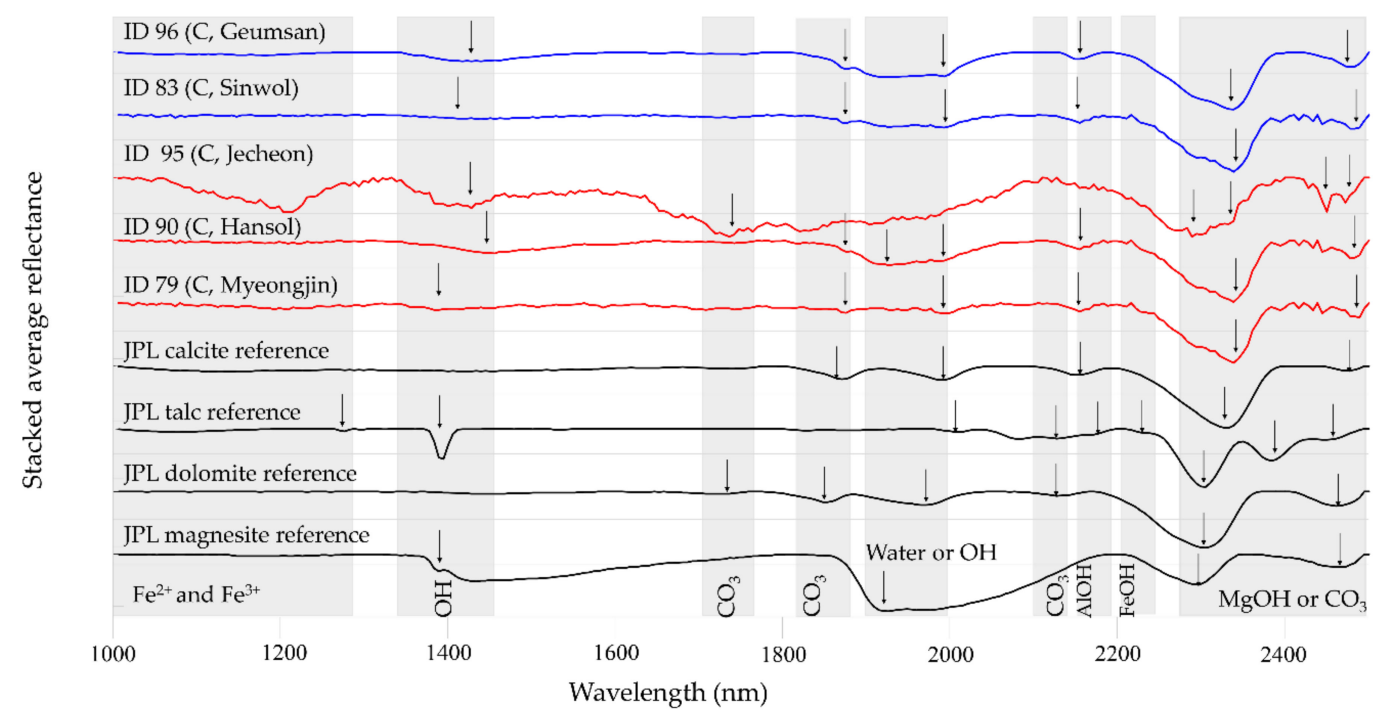

Figure 3. The average hull quotient corrected reflectance spectra of 2 groups of calcite sample pixels $($ red $=$ group 1 ; blue $=$ group 2$)$ compared with library reference spectra . 


\subsubsection{Spectral Characteristics of Talc}

Differently from those for other types of mineral, the spectral characteristics of talc samples showed dominant common absorption features at 1276, 1300, 1389, 1910, 2010, 2077, 2133, 2172, 2233, 2290, 2311, and $2383 \mathrm{~nm}$, which were manifested by talc, while minor variation by mineral composition was observed. Group 1 of Myeongjin has talc and dolomite as major minerals, with magnesite as an accessory mineral, showing additional absorption features at 1500, 1800, and $1900 \mathrm{~nm}$. Group 2 of Geumsan shows more distinctive talc spectral features at 1300, 1400, and $1530 \mathrm{~nm}$, where talc is the only major mineral. Group 3 includes samples from Dashiqiao, containing talc and calcite as major minerals and magnesite as an accessory mineral. This group showed additional absorptions of calcite at $1870 \mathrm{~nm}$. These results also confirmed the heterogeneous mineral compositions of naturally formed samples and associated complex variations in spectral curves (Figure 4).

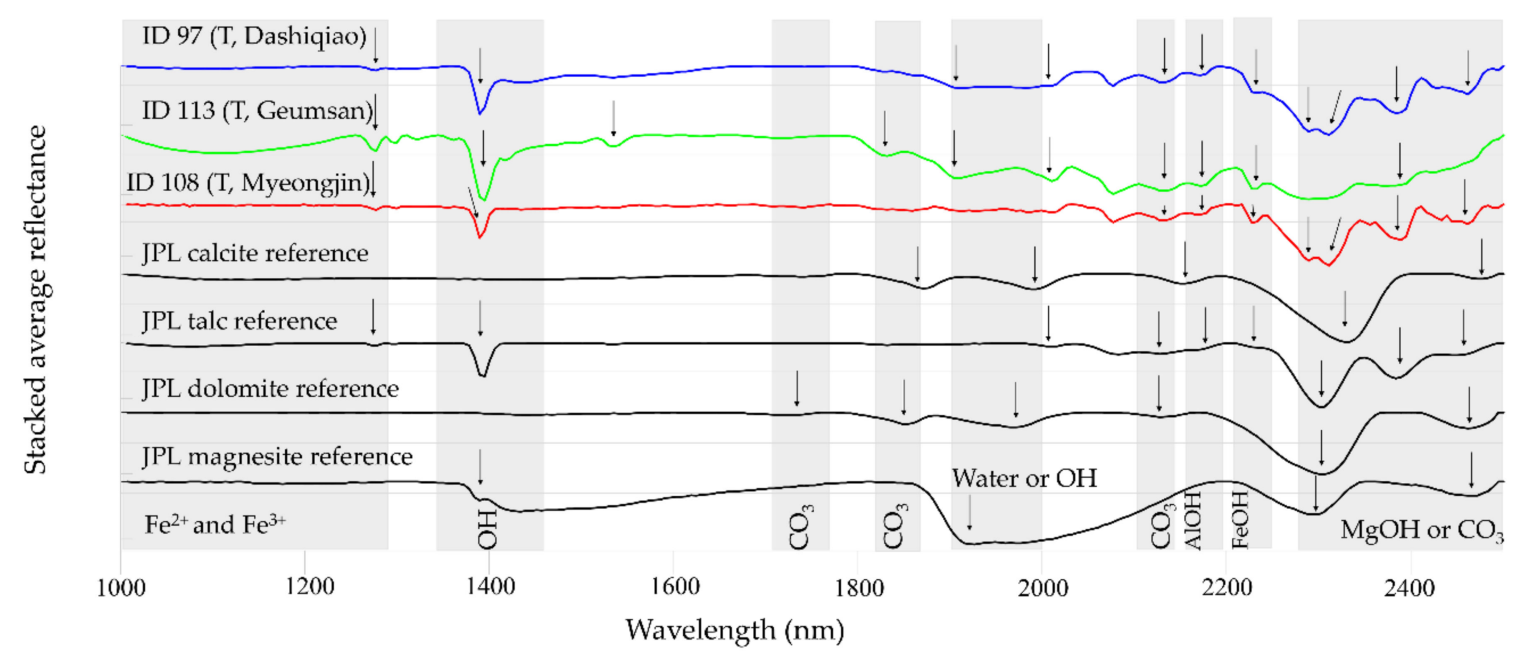

Figure 4. The average hull quotient corrected reflectance spectra of 3 groups of Talc sample pixels $($ red $=$ group 1 ; green $=$ group 2 ; blue $=$ group 3$)$ compared with the library reference spectra.

\subsubsection{Spectral Characteristics of Magnesite and Dolomite Associated with $\mathrm{MgO} / \mathrm{CaO}$ Content}

To figure out the spectral variations of magnesite and dolomite associated with $\mathrm{Mg} / \mathrm{Ca}$ content, we analyzed the spectral characteristics of magnesite and dolomite by the $\mathrm{MgO} / \mathrm{CaO}$ content (Figure 5). It is well known that the absorption feature of $\mathrm{Mg}-\mathrm{OH}$ around $2300 \mathrm{~nm}$ is associated with $\mathrm{MgO} / \mathrm{CaO}$ content $[25,70]$. The results showed a systematic shift of the $\mathrm{Mg}-\mathrm{OH}$ absorption toward a shorter wavelength, with an increase in $\mathrm{Mg}$ content regardless of source location. For example, the dolomite spectrum with a $\mathrm{MgO}$ content of $13.7 \%$ (ID 46) has the maximum absorption at $2322 \mathrm{~nm}$, and that with a $\mathrm{MgO}$ content of $21.9 \%$ (ID 55) has the maximum absorption at $2316 \mathrm{~nm}$, showing $6 \mathrm{~nm}$ of shift. The maximum absorption feature of $\mathrm{Mg}-\mathrm{OH}$ for magnesite samples was located at $2294 \mathrm{~nm}$. Compared to the dolomite spectrum of ID 46, the shift of $\mathrm{Mg}-\mathrm{OH}$ absorption is as much as $28 \mathrm{~nm}$. This study found the same phenomenon from the previous studies for the samples from various source locations $[25,70]$. It indicates that the shift of $\mathrm{Mg}-\mathrm{OH}$ absorption is a general phenomenon that may be useful for the detection of $\mathrm{Mg}$ content in dolomite and magnesite regardless of source location. 


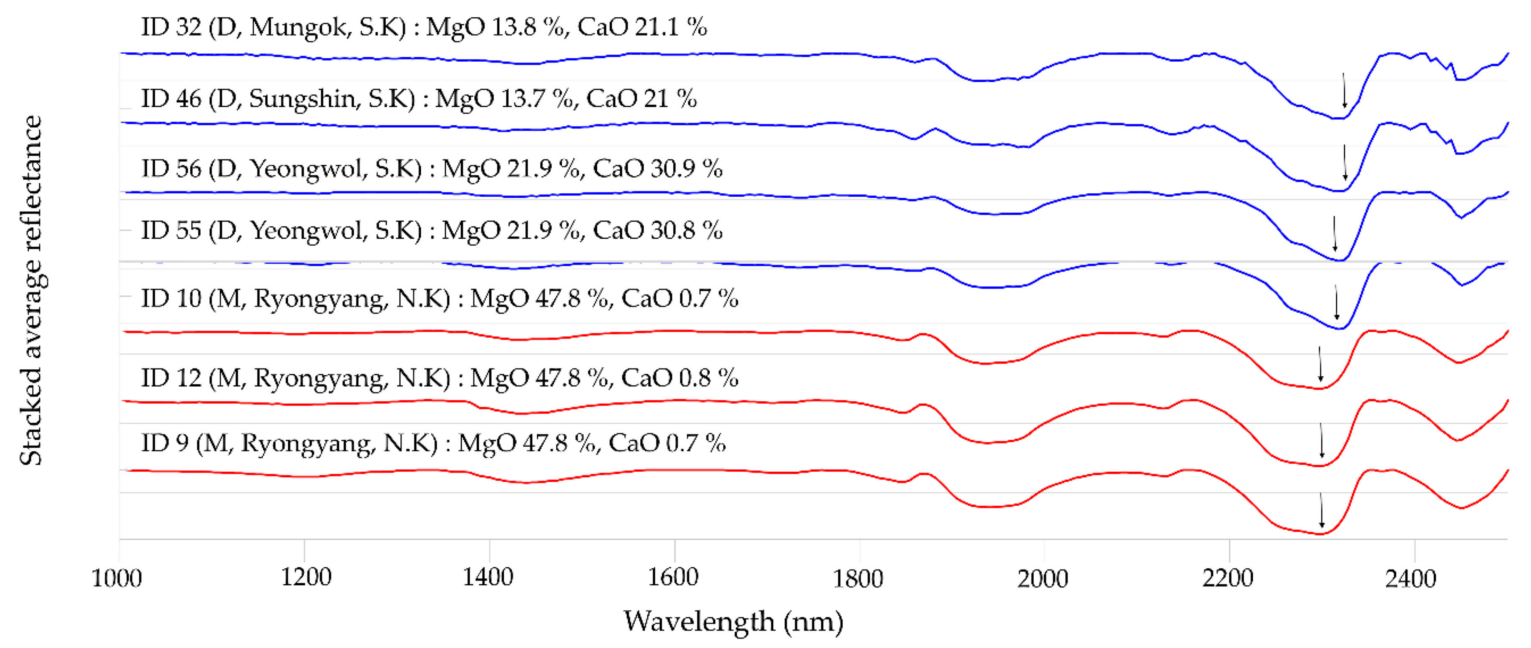

Figure 5. The spectral characteristics of magnesite (red lines) and dolomite samples (blue lines) associated with $\mathrm{MgO}$ content.

\subsection{Band Selection Based on the Random Forest Model}

We put the samples into the classification model of a random forest with Ntree $=500$ and Mtry $=70$. The model returned an overall accuracy of $98.2 \%$ (Table 4 ). The variable importance graph produced from the random forest algorithm (Figure 6) displayed the importance index of all of the input bands. [50] verified that the classification accuracy is superior if a sufficiently higher number of Ntree is used for the small number of variables. The smaller number of variables reduced variable collinearity, and thus could improve a multi-variate regression model. We selected 30 bands for the next step of analysis because, based on Figure 7, the out-of-bag (OOB) error was the lowest near 30 bands. The selected bands were mainly associated with $\mathrm{Mg}-\mathrm{OH}(2289-2384 \mathrm{~nm}), \mathrm{CO}_{3}(2467-2500 \mathrm{~nm})$, and $\mathrm{OH}$ (1389-1400 nm) (Figures 1 and 6).

Table 4. A confusion matrix for the random forest model used for band selection.

\begin{tabular}{|c|c|c|c|c|c|c|c|}
\hline & \multirow{2}{*}{ Class } & \multicolumn{6}{|c|}{ Predicted Class (Number of Pixels) } \\
\hline & & Magnesite & Dolomite & Talc & Other & Calcite & Accuracy (\%) \\
\hline \multirow{6}{*}{ 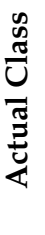 } & Magnesite & 985 & 1 & 4 & 7 & 3 & 98.5 \\
\hline & Dolomite & 3 & 964 & 2 & 10 & 21 & 99.6 \\
\hline & Talc & 0 & 3 & 996 & 0 & 1 & 99.6 \\
\hline & Other & 0 & 11 & 0 & 981 & 8 & 98.1 \\
\hline & Calcite & 3 & 8 & 0 & 7 & 982 & 98.2 \\
\hline & \multicolumn{6}{|c|}{ Overall Accuracy } & 98.2 \\
\hline
\end{tabular}

Among the 30 selected bands, the highest peak in Figure 6 is near the absorption feature of 2289-2384 $\mathrm{nm}$ by $\mathrm{Mg}-\mathrm{OH}$. This range has the major absorption features of magnesite, dolomite, calcite, and talc, with a minor shift between the minerals [34,71-73]. The second peak in terms of band importance corresponded to carbonate absorptions at 2467-2500nm (magnesite $2450 \mathrm{~nm}$, dolomite/talc $2460 \mathrm{~nm}$, and calcite $2470 \mathrm{~nm}$ ). Notably, the spectral region showed higher importance than the other absorption features associated with $\mathrm{CO}_{3}{ }^{2-}$ such as $1750 \mathrm{~nm}, 1870 \mathrm{~nm}, 1980 \mathrm{~nm}$, and $2160 \mathrm{~nm}[36,37,74,75]$. The minor shifts of absorption features in the bands between the minerals made the spectral region more effective for classification. The third largest peak comprises of the bands in the range 1389-1394 nm, which is the absorption caused by $\mathrm{OH}$. The spectral bands correspond with the absorption features of magnesite and talc. The selected 30 bands gave an OOB error of less than $1.5 \%$ from the RF model (Figure 7). The RF model provides an alternative dimension reduction method for hyperspectral data processing. 
120

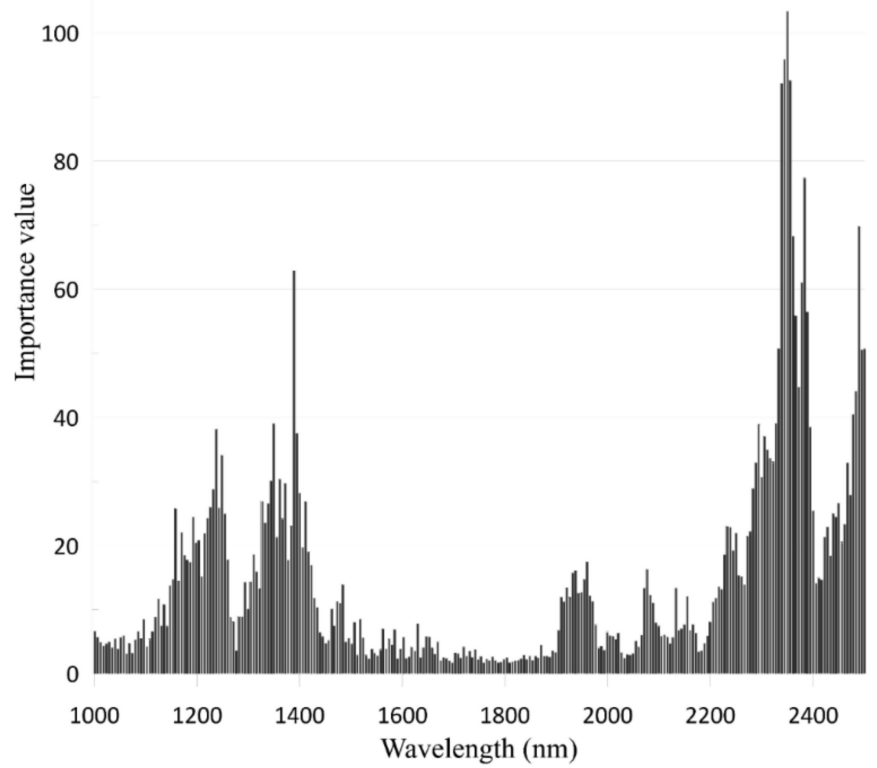

Figure 6. The importance values of spectral bands derived from the random forest (RF) method.

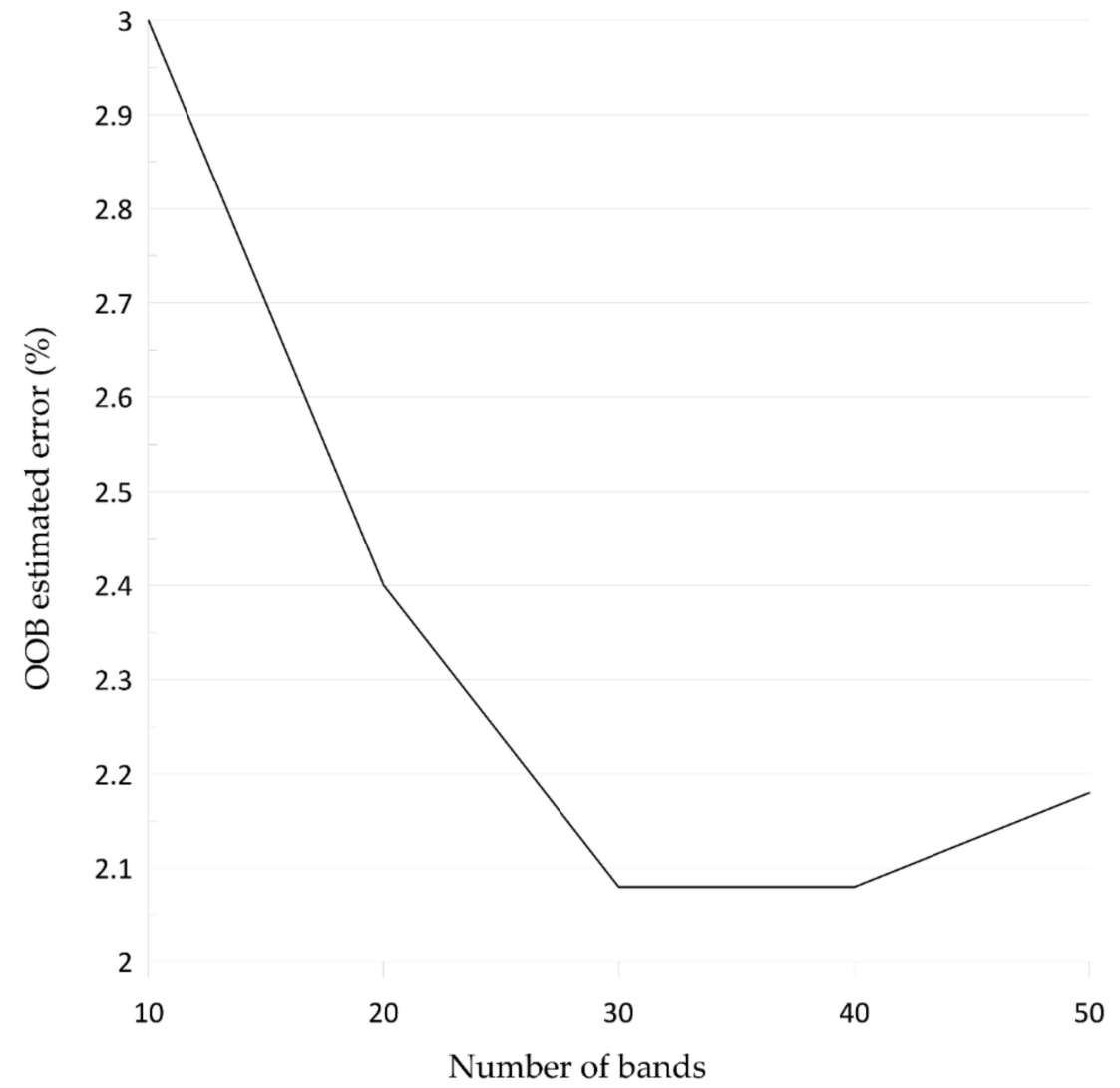

Figure 7. The results for out-of-bag $(\mathrm{OOB})$ errors, using the importance of bands in separating among the studied class. 


\subsection{Classification of Magnesite and Associated Gangue Minerals}

\subsubsection{Band Ratio}

Based on the combination of 30 selected bands, we derived two band ratio equations, following the band ratio driving method [22]. The band ratio equations were tested for all combinations of band math operations, and the final equations were selected based on Tamhane $\mathrm{T}_{2}$ and ANOVA tests with the best output results. The first band ratio combination was used to classify carbonate minerals and other types including talc, as Equation (6) below,

$$
\mathrm{Y}=\frac{B 2328 \times B 2389}{B 2344 \times B 2483}
$$

where B2328 is the spectral band of $2328 \mathrm{~nm}, \mathrm{~B} 2344$ is the spectral band of $2344 \mathrm{~nm}, \mathrm{~B} 2389$ is the spectral band of $2389 \mathrm{~nm}$, and B2483 is the spectral band of $2483 \mathrm{~nm}$, where the bands of B2328, B2344, and B2483 are related to the absorptions of carbonate minerals and band B2389 corresponds with the absorption shoulder. Then, the second band combination for the classification of carbonate minerals including magnesite, dolomite, and calcite was developed as in Equation (7)

$$
\mathrm{Y}=\frac{B 2294 \times B 2355}{B 2333 \times B 2383}
$$

where B2294 is the spectral band of $2294 \mathrm{~nm}, \mathrm{~B} 2333$ is the spectral band of $2333 \mathrm{~nm}, \mathrm{~B} 2355$ is the spectral band of $2355 \mathrm{~nm}$, and B2383 is the spectral band of $2383 \mathrm{~nm}$. B2294 discerns dolomite with higher reflectance than the reflectance of calcite. B2333, B2355, and B2383 show a high reflectance of magnesite and low reflectance of calcite, where absorption locations aligned in order of magnesite, dolomite, and calcite. B2294 is the major absorption band of magnesite, showing a higher reflectance of dolomite.

The classification results based on the band ratios derived above are presented in the box plot (Figure 8) [76]. The first band ratio showed median values for carbonate rock of 1.74, for other types of 1.2, and for talc of 0.65. As shown in Figure 8a, the first band ratio effectively classified carbonate minerals from talc, while the confusion between carbonate minerals and other types was expected. The overall accuracy of the classification was $82 \%$ (Table 5), yet the overall accuracy was acceptable, with the producer's accuracy for carbonate minerals being $63.9 \%$.

Table 5. A confusion matrix for the classification results of carbonate minerals, talc, and other types, by the band ratio method.

\begin{tabular}{ccccc}
\hline \multirow{2}{*}{ Class } & \multicolumn{4}{c}{ Predicted Class (Number of Pixels) } \\
\cline { 2 - 5 } & Talc & Other & Carbonate & Total \\
\hline Unclassified & 3 & 0 & 8 & 11 \\
Talc & 0 & 0 & 638 & 638 \\
Other & 829 & 6 & 42 & 877 \\
Carbonate & 168 & 994 & 312 & 1474 \\
Total & 1000 & 1000 & 1000 & 3000 \\
& User's accuracy (\%) & Producer's accuracy (\%) \\
Talc & \multicolumn{3}{c}{82.9} \\
Other & 94.5 & \multicolumn{3}{c}{99.4} \\
Carbonate & 67.4 & & 63.8 \\
\multicolumn{3}{c}{100} & & 82.0 \\
\hline
\end{tabular}

The second band ratio for the discrimination for carbonate minerals showed median values for magnesite of 0.71 , calcite of 0.91 , and dolomite of 1.02 . The range of the index is $0.56-0.88$ for magnesite, 0.75-1.08 for calcite, 0.94-1.12 for dolomite (Figure 8b). The overall accuracy of classification for 
the carbonate minerals was $55.2 \%$ (Table 6). However, the classification results for magnesite were acceptable, with a user's accuracy of $96 \%$.

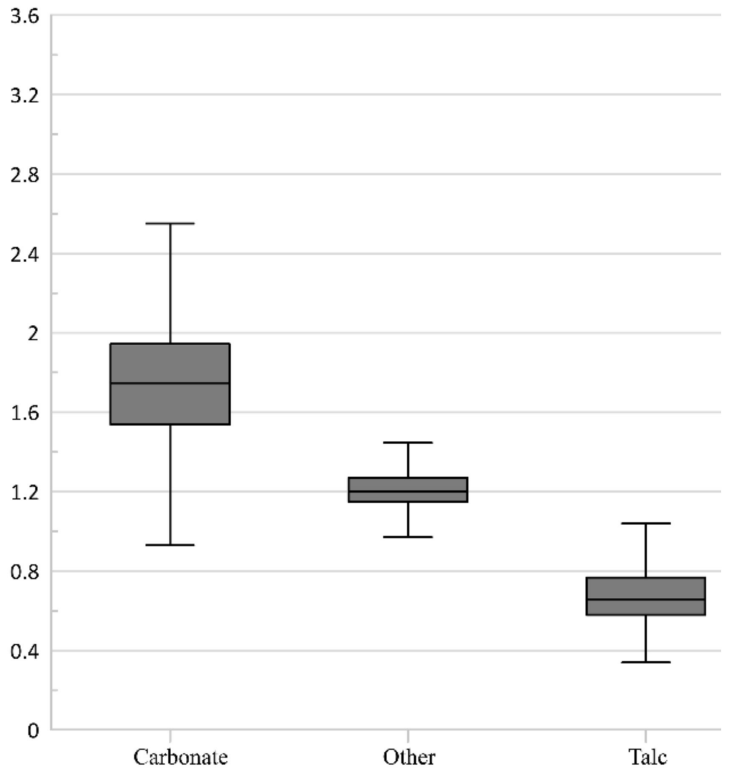

(a)

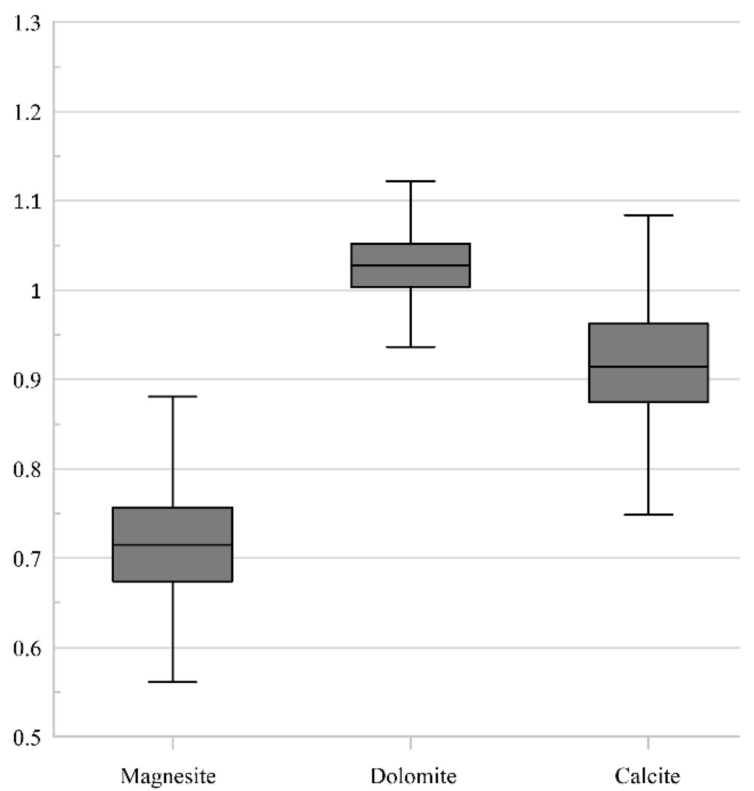

(b)

Figure 8. Box plots of the statistical indices for hyperspectral images transformed from the band ratios for carbonate minerals, talc, and other type classification (a), and the band ratios for magnesite, dolomite, and calcite classification (b).

Table 6. A confusion matrix for the classification results of magnesite, dolomite, and calcite based on the band ratio method.

\begin{tabular}{ccccc}
\hline \multirow{2}{*}{ Class } & \multicolumn{4}{c}{ Predicted Class (Number of Pixels) } \\
\cline { 2 - 5 } & Magnesite & Dolomite & Calcite & Total \\
\hline Unclassified & 0 & 14 & 8 & 22 \\
Magnesite & 684 & 0 & 28 & 712 \\
Dolomite & 0 & 25 & 16 & 41 \\
Calcite & 316 & 961 & 948 & 2225 \\
Total & 1000 & 1000 & 1000 & 3000 \\
& User's accuracy (\%) & Producer's accuracy (\%) \\
Magnesite & \multicolumn{3}{c}{68.4} \\
Dolomite & 96.1 & \multicolumn{3}{c}{02.5} \\
Calcite & 61.0 & & 94.8 \\
\multicolumn{2}{c}{ Overall accuracy (\%) } & 55.2 \\
\hline
\end{tabular}

\subsubsection{Binary Logistic Regression Models}

To overcome the limitation of the band ratio method and for better generalization, a binary logistic regression model was developed employing the 30 bands selected by the random forest method. Concerning the water bands-namely, the strong absorption wavelengths from water vapor at around 1400 and $1900 \mathrm{~nm}$ - because of their low signal to noise ratio [54], we excluded them from the regression model, resulting in 27 bands as the input variables for mineral prediction. Each mineral had one equation developed based on Equation (3) and by a step-wise variable selection mechanism to avoid multicollinearity. 
The stepwise variable selection for each target mineral is listed in Table 7. The classification equation for magnesite employed 11 variables, among which eight bands are associated with $\mathrm{Mg}-\mathrm{OH}$ spectral features, two bands are from Ca features, and one band is at $1237 \mathrm{~nm}$ (Table 7). For dolomite, the equation was developed based on nine bands from $\mathrm{Mg}-\mathrm{OH}$ features, four bands from Ca features, and one band at $1248 \mathrm{~nm}$ (Table 7). Differently from magnesite, seven bands were significant, and the most important bands were 2361 and $2489 \mathrm{~nm}$ of $\mathrm{Mg}-\mathrm{OH}$ features. The calcite equation was derived from nine bands from $\mathrm{Mg}-\mathrm{OH}$ features and four bands from Ca features, along with bands at 1237 and $1248 \mathrm{~nm}$. The band at $1248 \mathrm{~nm}$ plays an important role in calcite detection. Talc classification was based on seven bands of $\mathrm{Mg}-\mathrm{OH}$ features, four bands of Ca features, and the band at $1237 \mathrm{~nm}$ (Table 7), where $\mathrm{Mg}-\mathrm{OH}$ bands play important roles.

Table 7. The final selected variables in the equation and Wald test results from the logistic regression models.

\begin{tabular}{|c|c|c|c|c|c|c|}
\hline Variable & B1 & S.E.2 & Wald3 & Df4 & Sig. 5 & $\operatorname{Exp}(B) 6$ \\
\hline \multicolumn{7}{|c|}{ Final selected variables for magnesite classification } \\
\hline B1237 (1237 nm) & 44.2 & 10.237 & 18.642 & 1 & 0 & $1.57 \times 10^{19}$ \\
\hline B2294(2294 nm) & -1013.851 & 235.214 & 18.579 & 1 & 0 & 0 \\
\hline B2305 (2305 nm) & -1529.829 & 457.557 & 11.179 & 1 & 0.001 & 0 \\
\hline B2311 (2311 nm) & 1710.024 & 392.844 & 18.948 & 1 & 0 & 0 \\
\hline B2316 (2316 nm) & -1645.734 & 383.517 & 18.414 & 1 & 0 & 0 \\
\hline B2322 (2322 nm) & 1931.354 & 351.626 & 30.169 & 1 & 0 & 0 \\
\hline B2361 (2361 nm) & -362.818 & 88.704 & 16.73 & 1 & 0 & 0 \\
\hline B2389 (2389 nm) & 1629.333 & 339.902 & 22.978 & 1 & 0 & 0 \\
\hline B2394 (2394 nm) & -1253.898 & 306.746 & 16.71 & 1 & 0 & 0 \\
\hline B2467 (2467 nm) & 1211.941 & 268.864 & 20.319 & 1 & 0 & 0 \\
\hline B2478 $(2478 \mathrm{~nm})$ & -705.467 & 188.34 & 14.03 & 1 & 0 & 0 \\
\hline Constant & -11.785 & 2.24 & 27.674 & 1 & 0 & 0 \\
\hline \multicolumn{7}{|c|}{ Final selected variables for dolomite classification } \\
\hline B1248 (1248 nm) & -44.668 & 3.422 & 170.402 & 1 & 0 & 0 \\
\hline B2294 (2294 nm) & 289.719 & 32.46 & 79.663 & 1 & 0 & $6.66 \times 10^{125}$ \\
\hline B2316 (2316 nm) & -365.45 & 51.395 & 50.561 & 1 & 0 & 0 \\
\hline B2328 (2328 nm) & 238.129 & 63.567 & 14.033 & 1 & 0 & $2.62 \times 10^{103}$ \\
\hline B2339 (2339 nm) & -621.411 & 81.109 & 58.697 & 1 & 0 & 0 \\
\hline B2344 (2344 nm) & 132.733 & 69.632 & 3.634 & 1 & 0.057 & $4.42 \times 10^{57}$ \\
\hline B2355 (2355 nm) & 186.986 & 60.982 & 9.402 & 1 & 0.002 & $1.61 \times 10^{81}$ \\
\hline B2361 (2361 nm) & 615.639 & 71.841 & 73.436 & 1 & 0 & $2.34 \times 10^{267}$ \\
\hline B2383 (2383 nm) & -334.633 & 68.317 & 23.993 & 1 & 0 & 0 \\
\hline B2389 (2389 nm) & -182.19 & 67.463 & 7.293 & 1 & 0.007 & 0 \\
\hline B2467 (2467 nm) & 346.041 & 52.612 & 43.26 & 1 & 0 & $1.92 \times 10^{150}$ \\
\hline B2483 (2483 nm) & -382.869 & 79.088 & 23.436 & 1 & 0 & 0 \\
\hline B2489 (2489 nm) & 375.279 & 86.236 & 18.938 & 1 & 0 & $9.58 \times 10^{162}$ \\
\hline B2495 (2495 nm) & -268.606 & 63.377 & 17.962 & 1 & 0 & 0 \\
\hline Constant & -1.855 & 0.203 & 83.133 & 1 & 0 & 0.157 \\
\hline \multicolumn{7}{|c|}{ Final selected variables for calcite classification } \\
\hline B1237 (1237 nm) & -366.642 & 122.121 & 9.014 & 1 & 0.003 & 0.000 \\
\hline B1248 (1248 nm) & 338.763 & 121.725 & 7.745 & 1 & 0.005 & $1.327 \times 10^{147}$ \\
\hline B2311 (2311 nm) & -2798.173 & 460.679 & 36.894 & 1 & 0.000 & 0.000 \\
\hline B2316 (2316 nm) & 3090.930 & 506.840 & 37.191 & 1 & 0.000 & 0.000 \\
\hline B2339 (2339 nm) & 1640.527 & 312.480 & 27.563 & 1 & 0.000 & 0.000 \\
\hline $\mathrm{B} 2350(2350 \mathrm{~nm})$ & -1925.792 & 462.775 & 17.317 & 1 & 0.000 & 0.000 \\
\hline B2355 (2355 nm) & -2276.548 & 479.895 & 22.504 & 1 & 0.000 & 0.000 \\
\hline B2361 (2361 nm) & 2574.915 & 592.343 & 18.896 & 1 & 0.000 & 0.000 \\
\hline B2367 (2367 nm) & -1173.638 & 465.077 & 6.368 & 1 & 0.012 & 0.000 \\
\hline B2383 $(2383 \mathrm{~nm})$ & 3050.209 & 512.796 & 35.381 & 1 & 0.000 & 0.000 \\
\hline B2394 (2394 nm) & -2088.940 & 482.653 & 18.732 & 1 & 0.000 & 0.000 \\
\hline B2467 (2467 nm) & 1188.275 & 342.139 & 12.062 & 1 & 0.001 & 0.000 \\
\hline B2489 $(2489 \mathrm{~nm})$ & -3875.854 & 731.276 & 28.091 & 1 & 0.000 & 0.000 \\
\hline B2495 (2495 nm) & 3897.919 & 799.287 & 23.783 & 1 & 0.000 & 0.000 \\
\hline B2500 $(2500 \mathrm{~nm})$ & -1745.837 & 463.723 & 14.174 & 1 & 0.000 & 0.000 \\
\hline Constant & 0.952 & 0.842 & 1.278 & 1 & 0.258 & 2.591 \\
\hline
\end{tabular}


Table 7. Cont.

\begin{tabular}{ccccccc}
\hline Variable & B1 & S.E.2 & Wald3 & Df4 & Sig.5 & Exp(B)6 \\
\hline & \multicolumn{7}{c}{ Final selected } & variables for talc classification & & \\
B1237 $(1237 \mathrm{~nm})$ & 63.06 & 7.802 & 65.335 & 1 & 0 & $2.44 \times 10^{27}$ \\
B2294 $(2294 \mathrm{~nm})$ & 494.21 & 133.41 & 13.723 & 1 & 0 & $4.29 \times 10^{214}$ \\
B2322 $(2322 \mathrm{~nm})$ & -352.872 & 183.233 & 3.709 & 1 & 0.054 & 0 \\
B2333 $(2333 \mathrm{~nm})$ & -440.763 & 180.68 & 5.951 & 1 & 0.015 & 0 \\
B2344 $(2344 \mathrm{~nm})$ & 763.836 & 194.177 & 15.474 & 1 & 0 & 0 \\
B2355 $(2355 \mathrm{~nm})$ & -669.464 & 151.933 & 19.416 & 1 & 0 & 0 \\
B2372 $(2372 \mathrm{~nm})$ & 383.697 & 226.936 & 2.859 & 1 & 0.091 & $4.34 \times 10^{189}$ \\
B2383 $(2383 \mathrm{~nm})$ & -391.674 & 143.916 & 7.407 & 1 & 0.006 & 0 \\
B2467 $(2467 \mathrm{~nm})$ & -311.595 & 204.861 & 2.313 & 1 & 0.128 & 0 \\
B2478 $(2478 \mathrm{~nm})$ & 435.462 & 262.939 & 2.743 & 1 & 0.098 & $1.32 \times 10^{189}$ \\
B2495 $(2495 \mathrm{~nm})$ & 468.646 & 291.343 & 2.587 & 1 & 0.108 & $3.39 \times 10^{203}$ \\
B2500 $(2500 \mathrm{~nm})$ & -544.645 & 219.341 & 6.166 & 1 & 0.013 & 0 \\
Constant & -6.352 & 1.213 & 27.417 & 1 & 0 & 0.002 \\
\hline
\end{tabular}

$\mathrm{B}^{1}=$ logistic coefficient; S.E. ${ }^{2}=$ standard error of estimate; Wald $^{3}=$ Wald chi-square values; Df $^{4}=$ degree of freedom; Sig. ${ }^{5}=$ P-value; $\operatorname{Exp}(B)^{6}=$ exponentiated coefficient

All logistic regression equations employed the band at $2467 \mathrm{~nm}$, and three models employed the bands at 1237, 2294, 2316, 2355, 2361, and $2495 \mathrm{~nm}$. The absorption features associated with $\mathrm{Mg}-\mathrm{OH}$ and Ca participated in all regression equations, where the absorption depth, peak absorption, and absorption width vary among the target minerals. Exceptionally, the spectral band of $1237 \mathrm{~nm}$ participated in three regression models, even though the band has no absorption feature. The spectral signatures (1200 nm range) of the minerals show consistent low standard errors (Table 7). Indeed, [77] also used spectral features other than the $2000-2300 \mathrm{~nm}$ region for the detection and classification of carbonatites among sedimentary carbonates. Moreover, the RF algorithm identified $1200 \mathrm{~nm}$ as important spectral bands for the classification of target minerals. The overall accuracy of the classification was $99.9 \%$ for magnesite, $98 \%$ for dolomite, $99.6 \%$ for calcite, and $99.8 \%$ for talc (Table 8 ).

Table 8. An accuracy table for the classification results derived from binary logistic regression models.

\begin{tabular}{clccc}
\hline \multirow{2}{*}{ Observed } & \multicolumn{2}{c}{$\begin{array}{c}\text { Predicted (Number of Pixels) } \\
\text { No Event (0) }\end{array}$} & Correct Percentage \\
& & 3999 & 1 & 100 \\
\hline Magnesite & 0 & 5 & 995 & 99.5 \\
& 1 & & & 99.9 \\
\hline Dolomite & 0 & 77 & 25 & 99.4 \\
& 1 & 923 & 92.3 \\
& Overall Percentage & & 98.0 \\
\hline Calcite & 0 & 3991 & 9 & 99.8 \\
& 1 & 7 & 993 & 99.3 \\
& Overall Percentage & & 99.7 \\
\hline Talc & 0 & 3995 & 5 & 99.9 \\
& 1 & 5 & 995 & 99.5 \\
& Overall Percentage & & 99.8 \\
\hline
\end{tabular}

Evaluation of Binary Regression Models

The results of Hosmer and Lemeshow test showed that the $p$ values of the $X^{2}$ values of the logistic regression models for the target minerals range from 0.472 for dolomite to 0.997 for magnesite and calcite (Table 9). In general, significance higher than 0.05 is acceptable, and the test showed that all models are statistically coherent [64]. 
Table 9. The statistical parameters of the logistic regression models.

\begin{tabular}{|c|c|c|c|c|c|}
\hline \multirow{2}{*}{ Statistical Parameters } & \multicolumn{3}{|c|}{ Hosmer and Lemeshow Test } & \multicolumn{2}{|c|}{ Pseudo- $R^{2}$} \\
\hline & $X^{2}$ & df & P Value & Cox \& Snell $R^{2}$ & Nagelkerke $R^{2}$ \\
\hline Magnesite & 1.180 & 8 & 0.997 & 0.628 & 0.994 \\
\hline Dolomite & 7.613 & 8 & 0.472 & 0.580 & 0.917 \\
\hline Calcite & 1.129 & 8 & 0.997 & 0.625 & 0.988 \\
\hline Talc & 1.425 & 8 & 0.994 & 0.626 & 0.989 \\
\hline
\end{tabular}

In addition, the goodness of fit was tested based on pseudo- $R^{2}$, where pseudo- $R^{2}$ ranged from 0.58 to 0.628 for Cox \& Snell $R^{2}$, and 0.917 to 0.994 for Nagelkerke $R^{2}$ (Table 9). In general, Cox \& Snell pseudo- $R^{2}$ values larger than 0.2 are considered to indicate good fit [78]. The psuedo- $R^{2}$ values of the models validated that all models have a strong goodness of fit.

Validation of Binary Regression Models

The binary regression models for detection of magnesite, dolomite, calcite, and talc developed from training samples were applied to 46 validation samples (Figure 9). The accuracy of the magnesite logistic regression model was $97.6 \%$. All magnesite samples were correctly detected, while some pixels of magnesite samples were classified as none (Figure 9a and Table 10). The overall accuracy of the dolomite model was $82 \%$, where the model classified 9 out of 21 dolomite samples (Figure $9 \mathrm{~b}$ and Table 10). The accuracy of dolomite was lower than of the other minerals. The erroneous samples include calcite and/or quartz as major minerals (Table 2). The bias might be caused by the mix of major spectra manifested by both minerals. The calcite model classified $94.6 \%$ of calcite pixels correctly (Figure $9 \mathrm{c}$ and Table 10). The accuracy of the talc model was very high (99.8\%, Figure $9 \mathrm{~d}$ and Table 10).

Table 10. A confusion matrix for the classification results of the validation set from the binary regression models.

\begin{tabular}{cccccc}
\hline \multirow{2}{*}{ Class } & \multicolumn{2}{c}{ Correct Class } & \multicolumn{2}{c}{ Non Correct Class } & \multirow{2}{*}{$\begin{array}{c}\text { Overall } \\
\text { Accuracy (\%) }\end{array}$} \\
\cline { 2 - 5 } & $\begin{array}{c}\text { Producer's } \\
\text { Accuracy (\%) }\end{array}$ & $\begin{array}{c}\text { User's } \\
\text { Accuracy (\%) }\end{array}$ & $\begin{array}{c}\text { Producer's } \\
\text { Accuracy (\%) }\end{array}$ & $\begin{array}{c}\text { User's } \\
\text { Accuracy (\%) }\end{array}$ & \\
\hline Magnesite & 99.7 & 95.6 & 95.6 & 99.7 & 97.6 \\
Dolomite & 54.4 & 99.3 & 77.3 & 99.8 & 82 \\
Calcite & 47.6 & 71.1 & 95.9 & 98.4 & 94.6 \\
Talc & 99.5 & 92.31 & 99.8 & 99.9 & 99.8 \\
\hline
\end{tabular}




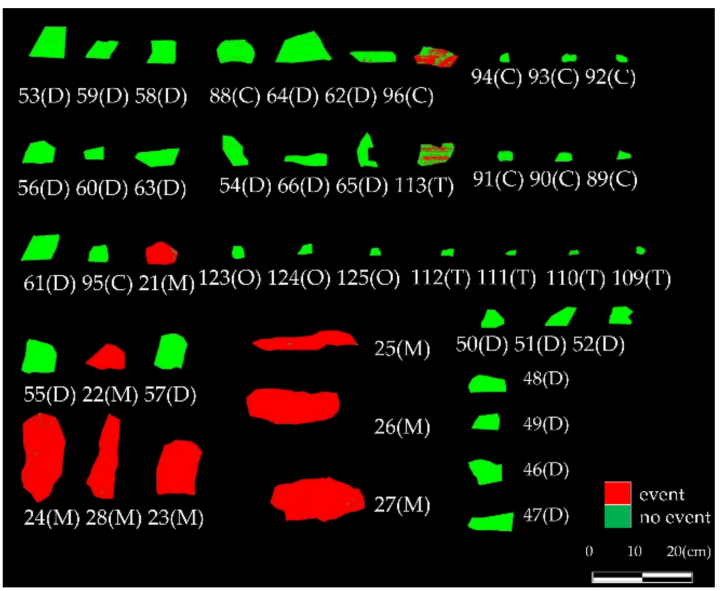

(a)

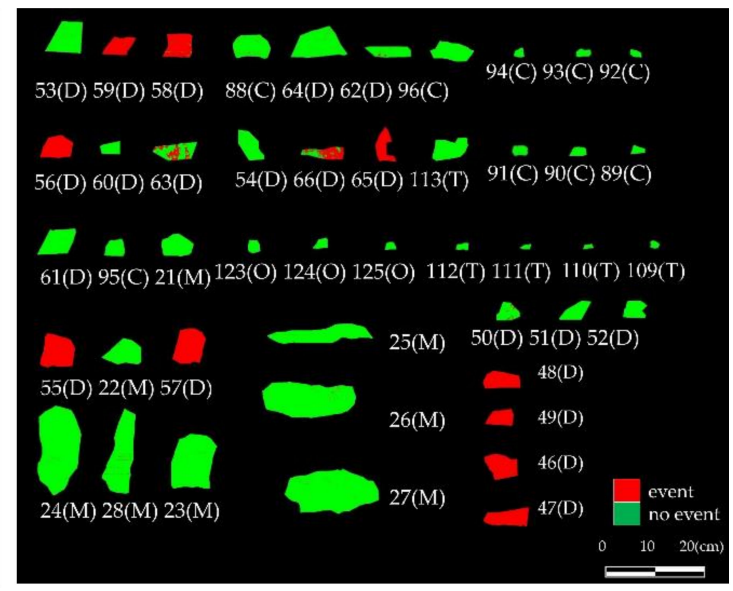

(b)

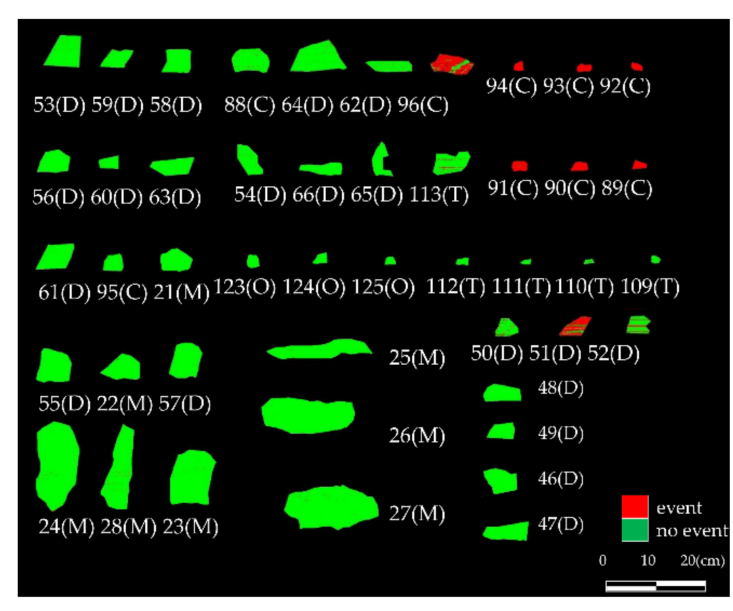

(c)

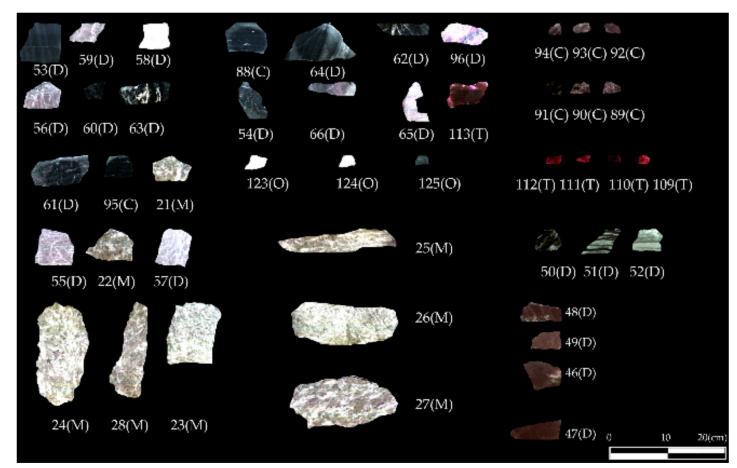

(e)

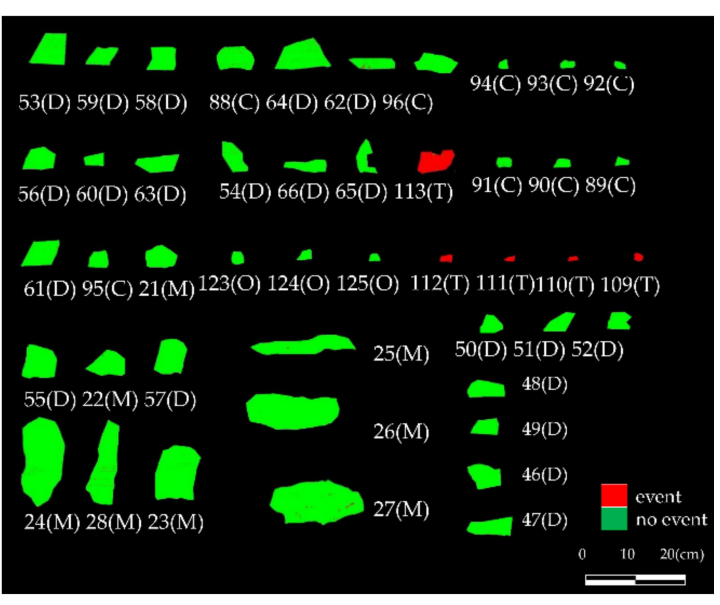

(d)

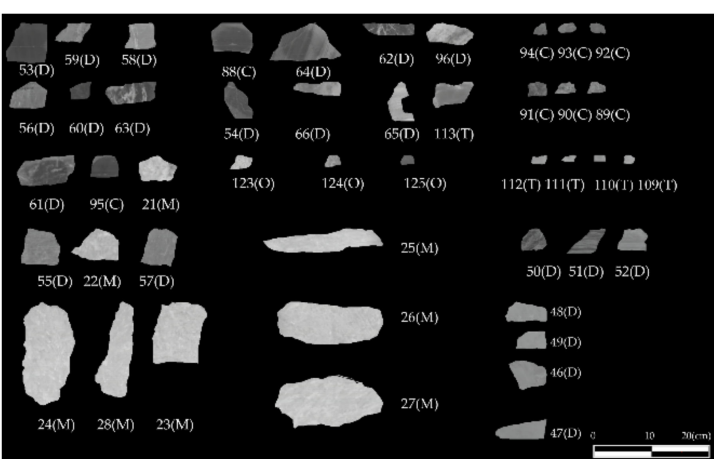

(f)

Figure 9. Classification images of the logistic regression models applied to the validation models of (a) magnesite, (b) dolomite, (c) calcite, and (d) talc; a Specim hyperspectral short wave infrared (SWIR) false color composite image (R:2250 nm; G:2283 nm; B:2433 nm) (e); and a gray scale image of the 2266 $\mathrm{nm}$ band (f) for the validation samples, where the sample label of $\mathrm{M}$ shows the magnesite sample, $\mathrm{D}$ the dolomite sample, $\mathrm{C}$ calcite, $\mathrm{T}$ talc, and $\mathrm{O}$ other types. 


\subsection{Discussions and Limitations of the Present Work}

Based on the classification results applied to the validation samples, the logistic regression models showed significantly higher accuracy than the band ratio method. While the band ratio method is easier to apply, its overall accuracy was about $40 \%$ lower than that of the logistic regression models for carbonate mineral classification. In addition, we compared the effectiveness of the logistic regression models with the RF method. The classification results of the RF method for the validation samples showed an accuracy ranging from $92.6 \%$ to $99.9 \%$, with an overall accuracy of $96.6 \%$ (Table 11 ). The accuracy of the RF method was similar with the logistic regression models except for the dolomite samples. The RF method showed better performance on dolomite classification, with 92.6\%. Although the RF method shows a slightly better accuracy, the knowledge learned by the RF algorithm is wrapped in its complex data structure as a black box to the researchers. On the contrary, the logistic models have simple form and can be easily generalized to other case studies for magnesite exploration.

Given the fact that this study developed the models using naturally occurring samples from various locations and that the mineral composition is heterogeneous, the models tested in this study could be applicable for real-world cases as prompt analytical methods for sample discrimination. Analysts can select the best model for their case studies. For hyperspectral band surveys, we recommend the logistic regression model.

Although our study is comprehensive on the band selection, the target minerals only include four major ones. It is not difficult to conclude that if more minerals are considered, the complexity of the prediction model will drastically increase. Furthermore, this study is based on fresh samples with controlled dry conditions. The weathering process and wet surface would complicate the spectral signals associated with hydrolysis and water components [38,79]. Adding controlled moisture and weathered samples would allow us to better understand the uncertainty in mapping magnesite in a natural environment. The band selection and band-ratio equations will be different under different assumptions of surface moisture and weathering. Our research proved the feasibility of the method we developed for fresh dry samples and could serve a role model for these future case studies.

Table 11. A confusion matrix for the classification results of the validation set from the random forest algorithm.

\begin{tabular}{ccccccc}
\hline \multirow{2}{*}{ Class } & \multicolumn{4}{c}{ Predicted Class (Number of Pixels) } \\
\cline { 3 - 7 } & & Magnesite & Dolomite & Talc & Calcite & Accuracy (\%) \\
\hline \multirow{3}{*}{ Actual Class } & Magnesite & 997 & 3 & 0 & 0 & 99.7 \\
& Dolomite & 2 & 926 & 0 & 72 & 92.6 \\
& Talc & 0 & 0 & 999 & 1 & 99.9 \\
& Calcite & 0 & 56 & 0 & 944 & 94.4 \\
& & Overall Accuracy (\%) & & & 96.6 \\
\hline
\end{tabular}

\section{Conclusions}

This study introduced a detection method for magnesite and associated gangue minerals including dolomite, calcite, and talc based on mineralogical, chemical, and hyperspectral analyses using SWIR hyperspectral images under laboratory conditions. The samples used for this study originated from thirteen different locations in South Korea, China, and North Korea and were used to develop detection models with wide applicability. The spectral characteristics of sample spectra were analyzed with consideration of minerals and composition. Using the spectral characteristics derived from the hyperspectral images, the random forest algorithm was used for band selection and dimension reduction. Band ratio and logistic regression models were developed to find the most useful detection methods.

The mineralogical analysis revealed the heterogeneity of mineral composition for naturally occurring samples. Magnesite samples contains accessory minerals such as dolomite, calcite, chabazite, clinochlore, quartz, and siderite. Dolomite and calcite samples showed the accessory minerals actinolite, augite, calcite, graphite, magnesite, phlogopite, quartz, and titanite. Talc samples had 
magnesite, dolomite, and calcite as accessory minerals. The results indicate the heterogeneity of mineral composition, even for the same types of sample. Because the mineral composition in one type of mineral showed large variations - mainly mixed forms of magnesite, dolomite, and calcite-the hyperspectral approaches for magnesite exploration must consider variations in mineral composition in other case studies. The $\mathrm{Mg}$ and Ca composition of magnesite and dolomite varied significantly, where magnesite had more $\mathrm{Mg}$ content and dolomite had more Ca content. These results confirmed the heterogeneity of minerals in not only the mineral composition but also the chemical composition of major elements.

The spectral characteristics of the magnesite samples were found at the absorption features located at 1850, 1930, 2130, 2300, and $2450 \mathrm{~nm}$, with weak absorptions at 1720 and $2360 \mathrm{~nm}$. The spectral characteristics represent the heterogeneity of mineral composition, where absorption features of dolomite, calcite, and talc were found in the spectra of magnesite samples. The same phenomenon was found for dolomite, calcite, and talc samples, where major absorptions of each mineral were mixed with other minerals' absorptions from the sample spectra, representing heterogeneous mineral composition. The spectral characteristics of magnesite and dolomite showed systematic variations in $\mathrm{Mg}-\mathrm{OH}$ absorption features toward a shorter wavelength, with an increase in $\mathrm{Mg}$ content. This indicates that the shift of $\mathrm{Mg}-\mathrm{OH}$ absorption may be useful for the detection of $\mathrm{Mg}$ content in dolomite and magnesite.

The random forest algorithm reduced the number of bands by selecting 30 of the most sensitive bands for the classification of magnesite and associated gangue minerals. The selected bands were mainly associated with $\mathrm{Mg}-\mathrm{OH}(2289-2384 \mathrm{~nm}), \mathrm{CO}_{3}(2467-2500 \mathrm{~nm})$, and OH (1389-1400 nm). Among the selected bands, the bands with the highest importance were found in spectral range of $\mathrm{Mg}-\mathrm{OH}$ absorptions, followed by the spectral bands around carbonate and hydrolysis absorptions. A two-step band ratio method was derived using the selected bands. The first step classified carbonate minerals from talc and other types of sample with an accuracy of $92 \%$. The second step classified magnesite, dolomite, and calcite with an accuracy of $55.2 \%$, where the classification results were not satisfactory. The logistic regression models based on the 27 selected bands excluding water bands achieved accuracies of 98\% 99.9\% for the training samples and 82-99.8\% for the validation samples.

Given the fact that this study found the naturally formed samples from various locations showing heterogeneous mineral composition, the applicability of the models would expand to general use as a prompt analytical method for sample discrimination. It is necessary to include more samples with more source locations to refine and enhance the model. Furthermore, the method would expand its applicability to carbonate rocks and minerals exploration significantly if the method was tested in the field.

Author Contributions: Conceptualization, J.Y. and B.C.; Methodology, J.Y. and B.C.; Software, B.C.; Validation, J.Y. and L.W.; Formal Analysis, B.C. and S.L.; Investigation, J.Y., B.C., and L.W.; Resources, Y.J., N.H.K., and B.H.L.; Data Curation, B.C. and N.H.K.; Writing-Original Draft Preparation, B.C. and J.Y.; Writing-Review \& Editing, J.Y. and L.W.; Visualization, B.C.; Supervision, J.Y.; Project Administration, J.Y., B.H.L., and S.K.; Funding Acquisition, J.Y. and S.K. All authors have read and agreed to the published version of the manuscript.

Funding: This work was supported by the National Research Council of Science \& Technology (NST) grant by the Korea Government (MSIT) (No. CRC-15-06-KIGAM) and the National Research Foundation (NRF) of Korea grant by the Korean Government (NRF-2020R1A2C200543911).

Acknowledgments: The authors deeply appreciate anonymous academic editor and reviewers for their constructive comments.

Conflicts of Interest: The authors declare no conflict of interest.

\section{References}

1. Salazar, K. Mineral Commodity Summaries 2013: US Geological Survey (USGS). US Geol. Surv. 2013. [CrossRef]

2. Park, H.-K.; Park, J.-T.; Lee, H.-I.; Choi, Y.-Y. Characteristics in Calcination of Magnesite Ore in Yongyang Mines. J. Korean Inst. Resour. Recycl. 2005, 14, 33-38. 
3. Sibanda, Z.; Amponsah-Dacosta, F.; Mhlongo, S. Characterization and evaluation of magnesite tailings for their potential utilization: A case study of nyala magnesite mine, limpopo province of South Africa. ARPN J. Eng. Appl. Sci. 2013, 8, 606-613.

4. Melezhik, V.A.; Fallick, A.E.; Medvedev, P.V.; Makarikhin, V.V. Palaeoproterozoic magnesite: Lithological and isotopic evidence for playa/sabkha environments. Sedimentology 2001, 48, 379-397. [CrossRef]

5. Lippmann, F. Sedimentary Carbonate Minerals; Springer Science \& Business Media: Heidelberg, Germany, 2012; Volume 6.

6. Machel, H.G. Concepts and models of dolomitization: A critical reappraisal. Geol. Soc. Lond. Spec. Publ. 2004, 235, 7-63. [CrossRef]

7. Pohl, W. Comparative geology of magnesite deposits and occurrences. Magnesite Geol. Mineral. Geochem. Form. Mg-Carbonates 1989, 28, 1-13.

8. Pohl, W. Genesis of magnesite deposits-Models and trends. Geol. Rundsch. 1990, 79, 291-299. [CrossRef]

9. Warren, J. Dolomite: Occurrence, evolution and economically important associations. Earth Sci. Rev. 2000, 52, 1-81. [CrossRef]

10. Baldermann, A.; Deditius, A.P.; Dietzel, M.; Fichtner, V.; Fischer, C.; Hippler, D.; Leis, A.; Baldermann, C.; Mavromatis, V.; Stickler, C.P. The role of bacterial sulfate reduction during dolomite precipitation: Implications from Upper Jurassic platform carbonates. Chem. Geol. 2015, 412, 1-14. [CrossRef]

11. Given, R.K.; Wilkinson, B.H. Dolomite abundance and stratigraphic age; constraints on rates and mechanisms of Phanerozoic dolostone formation. J. Sediment. Res. 1987, 57, 1068-1078. [CrossRef]

12. Budd, D. Cenozoic dolomites of carbonate islands: Their attributes and origin. Earth Sci. Rev. 1997, 42, 1-47. [CrossRef]

13. Prochaska, W. Genetic concepts on the formation of the Austrian magnesite and siderite mineralizations in the Eastern Alps of Austria. Geol. Croat. 2016, 69, 31-38. [CrossRef]

14. Misch, D.; Pluch, H.; Mali, H.; Ebner, F.; Huang, H. Genesis of giant Early Proterozoic magnesite and related talc deposits in the Mafeng area, Liaoning Province, NE China. J. Asian Earth Sci. 2018, 160, 1-12. [CrossRef]

15. Neubauer, F. Structural Control on the Formation of Ttalc Deposits; Balkeema Publ.: Lassing, Austria, 2001.

16. Railsback, L.B. Patterns in the compositions, properties, and geochemistry of carbonate minerals. Carbonates Evaporites 1999, 14, 1. [CrossRef]

17. Tangestani, M.H.; Moore, F. Iron oxide and hydroxyl enhancement using the Crosta Method: A case study from the Zagros Belt, Fars Province, Iran. Int. J. Appl. Earth Obs. Geoinf. 2000, 2, 140-146. [CrossRef]

18. Yip, C.K.; Provis, J.L.; Lukey, G.C.; van Deventer, J.S. Carbonate mineral addition to metakaolin-based geopolymers. Cem. Concr. Compos. 2008, 30, 979-985. [CrossRef]

19. Friedman, G.M. Identification of carbonate minerals by staining methods. J. Sediment. Res. 1959, $29,87-97$. [CrossRef]

20. Dickson, J. Carbonate identification and genesis as revealed by staining. J. Sediment. Res. 1966, 36, 491-505. [CrossRef]

21. Laakso, K.; Middleton, M.; Heinig, T.; Bärs, R.; Lintinen, P. Assessing the ability to combine hyperspectral imaging (HSI) data with Mineral Liberation Analyzer (MLA) data to characterize phosphate rocks. Int. J. Appl. Earth Obs. Geoinf. 2018, 69, 1-12. [CrossRef]

22. Rajendran, S.; Hersi, O.S.; Al-Harthy, A.; Al-Wardi, M.; El-Ghali, M.A.; Al-Abri, A.H. Capability of advanced spaceborne thermal emission and reflection radiometer (ASTER) on discrimination of carbonates and associated rocks and mineral identification of eastern mountain region (Saih Hatat window) of Sultanate of Oman. Carbonates Evaporites 2011, 26, 351-364. [CrossRef]

23. Rajendran, S.; Nasir, S. ASTER spectral analysis of ultramafic lamprophyres (carbonatites and aillikites) within the Batain Nappe, northeastern margin of Oman: A proposal developed for spectral absorption. Int. J. Remote Sens. 2013, 34, 2763-2795. [CrossRef]

24. Rajendran, S.; Nasir, S.; Kusky, T.M.; Ghulam, A.; Gabr, S.; El-Ghali, M.A. Detection of hydrothermal mineralized zones associated with listwaenites in Central Oman using ASTER data. Ore Geol. Rev. 2013, 53, 470-488. [CrossRef]

25. Mars, J.C.; Rowan, L.C. Spectral assessment of new ASTER SWIR surface reflectance data products for spectroscopic mapping of rocks and minerals. Remote Sens. Environ. 2010, 114, 2011-2025. [CrossRef]

26. Amer, R.; Kusky, T.; Ghulam, A. Lithological mapping in the Central Eastern Desert of Egypt using ASTER data. J. Afr. Earth Sci. 2010, 56, 75-82. [CrossRef] 
27. Gabr, S.; Ghulam, A.; Kusky, T. Detecting areas of high-potential gold mineralization using ASTER data. Ore Geol. Rev. 2010, 38, 59-69. [CrossRef]

28. Kruse, F.A.; Boardman, J.W.; Huntington, J.F. Comparison of airborne hyperspectral data and EO-1 Hyperion for mineral mapping. IEEE Trans. Geosci. Remote Sens. 2003, 41, 1388-1400. [CrossRef]

29. Kodikara, G.R.; Woldai, T.; van Ruitenbeek, F.J.; Kuria, Z.; van der Meer, F.; Shepherd, K.D.; Van Hummel, G. Hyperspectral remote sensing of evaporate minerals and associated sediments in Lake Magadi area, Kenya. Int. J. Appl. Earth Obs. Geoinf. 2012, 14, 22-32. [CrossRef]

30. Govil, H.; Gill, N.; Rajendran, S.; Santosh, M.; Kumar, S. Identification of new base metal mineralization in Kumaon Himalaya, India, using hyperspectral remote sensing and hydrothermal alteration. ORE Geol. Rev. 2018, 92, 271-283. [CrossRef]

31. Jain, R.; Sharma, R.U. Airborne hyperspectral data for mineral mapping in Southeastern Rajasthan, India. Int. J. Appl. Earth Obs. Geoinf. 2019, 81, 137-145. [CrossRef]

32. Carrino, T.A.; Crósta, A.P.; Toledo, C.L.B.; Silva, A.M. Hyperspectral remote sensing applied to mineral exploration in southern Peru: A multiple data integration approach in the Chapi Chiara gold prospect. Int. J. Appl. Earth Obs. Geoinf. 2018, 64, 287-300. [CrossRef]

33. Krupnik, D.; Khan, S.; Okyay, U.; Hartzell, P.; Zhou, H.-W. Study of Upper Albian rudist buildups in the Edwards Formation using ground-based hyperspectral imaging and terrestrial laser scanning. Sediment. Geol. 2016, 345, 154-167. [CrossRef]

34. Baissa, R.; Labbassi, K.; Launeau, P.; Gaudin, A.; Ouajhain, B. Using HySpex SWIR-320m hyperspectral data for the identification and mapping of minerals in hand specimens of carbonate rocks from the Ankloute Formation (Agadir Basin, Western Morocco). J. Afr. Earth Sci. 2011, 61, 1-9. [CrossRef]

35. Zaini, N.; Van der Meer, F.; Van der Werff, H. Determination of carbonate rock chemistry using laboratory-based hyperspectral imagery. Remote Sens. 2014, 6, 4149-4172. [CrossRef]

36. Hunt, G.R.; Salisbury, J.W. Visible and near infrared spectra of minerals and rocks. II. Carbonates. Mod. Geol. 1971, 2, 23-30.

37. Gaffey, S.J. Spectral reflectance of carbonate minerals in the visible and near infrared (0.35-2.55 microns); calcite, aragonite, and dolomite. Am. Mineral. 1986, 71, 151-162.

38. Shin, J.H.; Yu, J.; Wang, L.; Kim, J.; Koh, S.-M.; Kim, S.-O. Spectral responses of heavy metal contaminated soils in the vicinity of a hydrothermal ore deposit: A case study of Boksu Mine, South Korea. IEEE Trans. Geosci. Remote Sens. 2019, 57, 4092-4106. [CrossRef]

39. Quinn, T. About Magforum. 2017; ISSN 1756-364X.

40. Kruse, F.A.; Bedell, R.L.; Taranik, J.V.; Peppin, W.A.; Weatherbee, O.; Calvin, W.M. Mapping alteration minerals at prospect, outcrop and drill core scales using imaging spectrometry. Int. J. Remote Sens. 2012, 33, 1780-1798. [CrossRef]

41. Smith, G.M.; Milton, E.J. The use of the empirical line method to calibrate remotely sensed data to reflectance. Int. J. Remote Sens. 1999, 20, 2653-2662. [CrossRef]

42. Green, A.A.; Berman, M.; Switzer, P.; Craig, M.D. A transformation for ordering multispectral data in terms of image quality with implications for noise removal. IEEE Trans. Geosci. Remote Sens. 1988, 26, 65-74. [CrossRef]

43. Shawky, M.M.; El-Arafy, R.A.; El Zalaky, M.A.; Elarif, T. Validating (MNF) transform to determine the least inherent dimensionality of ASTER image data of some uranium localities at Central Eastern Desert, Egypt. J. Afr. Earth Sci. 2019, 149, 441-450. [CrossRef]

44. Kokaly, R.F.; Clark, R.N. Spectroscopic determination of leaf biochemistry using band-depth analysis of absorption features and stepwise multiple linear regression. Remote Sens. Environ. 1999, 67, 267-287. [CrossRef]

45. Breiman, L. Random forests. Mach. Learn. 2001, 45, 5-32. [CrossRef]

46. Guo, L.; Chehata, N.; Mallet, C.; Boukir, S. Relevance of airborne lidar and multispectral image data for urban scene classification using Random Forests. ISPRS J. Photogramm. Remote Sens. 2011, 66, 56-66. [CrossRef]

47. Rodriguez-Galiano, V.F.; Ghimire, B.; Rogan, J.; Chica-Olmo, M.; Rigol-Sanchez, J.P. An assessment of the effectiveness of a random forest classifier for land-cover classification. ISPRS J. Photogramm. Remote Sens. 2012, 67, 93-104. [CrossRef] 
48. Abdel-Rahman, E.M.; Mutanga, O.; Adam, E.; Ismail, R. Detecting Sirex noctilio grey-attacked and lightning-struck pine trees using airborne hyperspectral data, random forest and support vector machines classifiers. ISPRS J. Photogramm. Remote Sens. 2014, 88, 48-59. [CrossRef]

49. Lawrence, R.L.; Wood, S.D.; Sheley, R.L. Mapping invasive plants using hyperspectral imagery and Breiman Cutler classifications (RandomForest). Remote Sens. Environ. 2006, 100, 356-362. [CrossRef]

50. Gislason, P.O.; Benediktsson, J.A.; Sveinsson, J.R. Random forests for land cover classification. Pattern Recognit. Lett. 2006, 27, 294-300. [CrossRef]

51. Kim, M.S.; Chen, Y.-R.; Cho, B.-K.; Chao, K.; Yang, C.-C.; Lefcourt, A.M.; Chan, D. Hyperspectral reflectance and fluorescence line-scan imaging for online defect and fecal contamination inspection of apples. Sens. Instrum. Food Qual. Saf. 2007, 1, 151. [CrossRef]

52. Ninomiya, Y.; Fu, B.; Cudahy, T.J. Detecting lithology with Advanced Spaceborne Thermal Emission and Reflection Radiometer (ASTER) multispectral thermal infrared "radiance-at-sensor" data. Remote Sens. Environ. 2005, 99, 127-139. [CrossRef]

53. Rajendran, S.; Al-Khirbash, S.; Pracejus, B.; Nasir, S.; Al-Abri, A.H.; Kusky, T.M.; Ghulam, A. ASTER detection of chromite bearing mineralized zones in Semail Ophiolite Massifs of the northern Oman Mountains: Exploration strategy. ORE Geol. Rev. 2012, 44, 121-135. [CrossRef]

54. Kurz, T.H.; Dewit, J.; Buckley, S.J.; Thurmond, J.B.; Hunt, D.W.; Swennen, R. Hyperspectral image analysis of different carbonate lithologies (limestone, karst and hydrothermal dolomites): The Pozalagua Quarry case study (Cantabria, North-west Spain). Sedimentology 2012, 59, 623-645. [CrossRef]

55. Gad, S.; Kusky, T. ASTER spectral ratioing for lithological mapping in the Arabian-Nubian shield, the Neoproterozoic Wadi Kid area, Sinai, Egypt. Gondwana Res. 2007, 11, 326-335. [CrossRef]

56. Kay, D.; Crowther, J.; Stapleton, C.M.; Wyer, M.D.; Fewtrell, L.; Edwards, A.; Francis, C.; McDonald, A.T.; Watkins, J.; Wilkinson, J. Faecal indicator organism concentrations in sewage and treated effluents. Water Res. 2008, 42, 442-454. [CrossRef] [PubMed]

57. Agresti, A. Categorical Data Analysis. John Wiley \& Sons: Hoboken, NJ, USA, 2003; Volume 482.

58. Hair, J.F.; Black, W.C.; Babin, B.J.; Anderson, R.E.; Tatham, R.L. Multivariate Data Analysis; Pearson Prentice Hall: Upper Saddle River, NJ, USA, 2006; Volume 6.

59. Pohar, M.; Blas, M.; Turk, S. Comparison of logistic regression and linear discriminant analysis: A simulation study. Metodoloski Zv. 2004, 1, 143.

60. Yousefi, M.; Carranza, E.J.M. Prediction-area (P-A) plot and C-A fractal analysis to classify and evaluate evidential maps for mineral prospectivity modeling. Comput. Geosci. 2015, 79, 69-81. [CrossRef]

61. Bewick, V.; Cheek, L.; Ball, J. Statistics review 14: Logistic regression. Crit. Care 2005, 9, 112. [CrossRef]

62. Hosmer Jr, D.W.; Lemeshow, S.; Sturdivant, R.X. Applied Logistic Regression; John Wiley \& Sons: New Jersey, NJ, USA, 2013; Volume 398.

63. Sahoo, N.R.; Pandalai, H.S. Integration of Sparse Geologic Information in Gold Targeting Using Logistic Regression Analysis in the Hutti-Maski Schist Belt, Raichur, Karnataka, India-A Case Study. Nat. Resour. Res. 1999, 8, 233-250. [CrossRef]

64. Mokhtari, A.R. Hydrothermal alteration mapping through multivariate logistic regression analysis of lithogeochemical data. J. Geochem. Explor. 2014, 145, 207-212. [CrossRef]

65. Hosmer, D.W.; Lemeshow, S. Applied Logistic Regression; John Wiley \& Sons,: New York, NJ, USA, 1989.

66. Menard, S. Coefficients of determination for multiple logistic regression analysis. Am. Stat. 2000, 54, 17-24.

67. Nagelkerke, N.J. A note on a general definition of the coefficient of determination. Biometrika 1991, 78, 691-692. [CrossRef]

68. Ayalew, L.; Yamagishi, H. The application of GIS-based logistic regression for landslide susceptibility mapping in the Kakuda-Yahiko Mountains, Central Japan. Geomorphology 2005, 65, 15-31. [CrossRef]

69. Kell-Duivestein, I.J.; Baldermann, A.; Mavromatis, V.; Dietzel, M. Controls of temperature, alkalinity and calcium carbonate reactant on the evolution of dolomite and magnesite stoichiometry and dolomite cation ordering degree-An experimental approach. Chem. Geol. 2019, 529, 119292. [CrossRef]

70. Combe, J.P.; Launeau, P.; Pinet, P.; Despan, D.; Harris, E.; Ceuleneer, G.; Sotin, C. Mapping of an ophiolite complex by high-resolution visible-infrared spectrometry. Geochem. Geophys. Geosystems 2006, 7. [CrossRef]

71. Hauff, P. An Overview of VIS-NIR-SWIR Field Spectroscopy as Applied to Precious Metals Exploration; Spectral International Inc.: Arvada, CO, USA, 2008; Volume 80001, pp. 303-403. 
72. Ben-Dor, E. Characterization of soil properties using reflectance spectroscopy. In Hyperspectral Remote Sensing of Vegetation; CRC Press: Boca Raton, FL, USA, 2016; pp. 548-593.

73. Bishop, J.; Lane, M.; Dyar, M.; Brown, A. Reflectance and emission spectroscopy study of four groups of phyllosilicates: Smectites, kaolinite-serpentines, chlorites and micas. Clay Miner. 2008, 43, 35-54. [CrossRef]

74. Clark, R.N.; King, T.V.; Klejwa, M.; Swayze, G.A.; Vergo, N. High spectral resolution reflectance spectroscopy of minerals. J. Geophys. Res. Solid Earth 1990, 95, 12653-12680. [CrossRef]

75. Crowley, J.K. Visible and near-infrared spectra of carbonate rocks: Reflectance variations related to petrographic texture and impurities. J. Geophys. Res. Solid Earth 1986, 91, 5001-5012. [CrossRef]

76. Hoaglin, D.C.; Mosteller, F.; Tukey, J.W. Understanding Robust and Exploratory Data Analysis; Wiley: New York, NY, USA, 1983; Volume 3.

77. Shavers, E.J.; Ghulam, A.; Encarnacion, J. Surface alteration of a melilitite-clan carbonatite and the potential for remote carbonatite detection. ORE Geol. Rev. 2018, 92, 19-28. [CrossRef]

78. Clark, W.; Hoskings, P. Statistical methods for geographers. In Clark Statistical Methods for Geographers; John Wiley and Sons: New York, NY, USA, 1986.

79. Shin, H.; Yu, J.; Jeong, Y.; Wang, L.; Yang, D. Case-based regression models defining the relationships between moisture content and shortwave infrared reflectance of beach sands. IEEE J. Sel. Top. Appl. Earth Obs. Remote Sens. 2017, 10, 4512-4521. [CrossRef]

(C) 2020 by the authors. Licensee MDPI, Basel, Switzerland. This article is an open access article distributed under the terms and conditions of the Creative Commons Attribution (CC BY) license (http://creativecommons.org/licenses/by/4.0/). 